Atmos. Chem. Phys., 17, 13869-13890, 2017

https://doi.org/10.5194/acp-17-13869-2017

(c) Author(s) 2017. This work is distributed under

the Creative Commons Attribution 3.0 License.

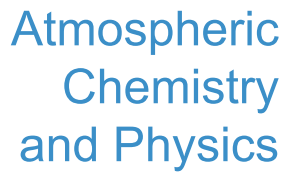

(c) (P)

\title{
Reanalysis of and attribution to near-surface ozone concentrations in Sweden during 1990-2013
}

\author{
Camilla Andersson $^{1}$, Heléne Alpfjord ${ }^{1}$, Lennart Robertson ${ }^{1}$, Per Erik Karlsson ${ }^{2}$, and Magnuz Engardt ${ }^{1}$ \\ ${ }^{1}$ Swedish Meteorological and Hydrological Institute, 60176 Norrköping, Sweden \\ ${ }^{2}$ Swedish Environmental Research Institute, P.O. Box 53021, 40014 Gothenburg, Sweden \\ Correspondence to: Camilla Andersson (camilla.andersson@smhi.se)
}

Received: 11 April 2017 - Discussion started: 20 June 2017

Revised: 21 September 2017 - Accepted: 14 October 2017 - Published: 22 November 2017

\begin{abstract}
We have constructed two data sets of hourly resolution reanalyzed near-surface ozone $\left(\mathrm{O}_{3}\right)$ concentrations for the period 1990-2013 for Sweden. Long-term simulations from a chemistry-transport model (CTM) covering Europe were combined with hourly ozone concentration observations at Swedish and Norwegian background measurement sites using retrospective variational data analysis. The reanalysis data sets show improved performance over the original CTM when compared to independent observations.

In one of the reanalyses, we included all available hourly near-surface $\mathrm{O}_{3}$ observations, whilst in the other we carefully selected time-consistent observations. Based on the second reanalysis we investigated statistical aspects of the distribution of the near-surface $\mathrm{O}_{3}$ concentrations, focusing on the linear trend over the 24-year period. We show that high nearsurface $\mathrm{O}_{3}$ concentrations are decreasing and low $\mathrm{O}_{3}$ concentrations are increasing, which is reflected in observed improvement of many health and vegetation indices (apart from those with a low threshold).

Using the CTM we also conducted sensitivity simulations to quantify the causes of the observed change, focusing on three factors: change in hemispheric background concentrations, meteorology and anthropogenic emissions. The rising low concentrations of near-surface $\mathrm{O}_{3}$ in Sweden are caused by a combination of all three factors, whilst the decrease in the highest $\mathrm{O}_{3}$ concentrations is caused by European $\mathrm{O}_{3}$ precursor emissions reductions.

While studying the impact of anthropogenic emissions changes, we identified systematic differences in the modeled trend compared to observations that must be caused by incorrect trends in the utilized emissions inventory or by too high sensitivity of our model to emissions changes.
\end{abstract}

\section{Introduction}

Elevated concentrations of near-surface ozone $\left(\mathrm{O}_{3}\right)$ are a major policy concern given their ability to damage both vegetation (e.g., Royal Society, 2008) and human health (e.g., WHO, 2006). It is also an important greenhouse gas (e.g., Stocker et al., 2013). Elevated $\mathrm{O}_{3}$ concentrations are formed in the troposphere by the oxidation of volatile organic compounds (VOCs) and carbon monoxide (CO), driven by solar radiation in a polluted air mixture that includes nitrogen oxides $\left(\mathrm{NO}_{x}\right.$, sum of nitric oxide and nitrogen dioxide: $\mathrm{NO}+\mathrm{NO}_{2}$ ). Close to combustion sources, the background $\mathrm{O}_{3}$ concentrations are reduced through reactions with directly emitted NO (see for example Finlayson-Pitts and Pitts, 2000). However, further away from the source and with sufficient availability of VOCs and under favorable weather conditions these $\mathrm{NO}_{x}$ emissions can lead to rises in the $\mathrm{O}_{3}$ concentration. $\mathrm{O}_{3}$ can be transported to regions far away from the area where it was formed and even across continents (e.g., Akimoto, 2003; Derwent et al., 2015). Oxidized nitrogen can also be transported to remote regions as reservoir species, such as peroxy-acetyl nitrates (PANs). These can be a significant source of $\mathrm{NO}_{x}$, and alongside naturally emitted biogenic VOCs, cause $\mathrm{O}_{3}$ formation in otherwise non-polluted areas (e.g., Jacob et al., 1993; Fiore et al., 2011).

European and North American anthropogenic emissions of $\mathrm{NO}_{x}$ increased over most of the 20th century, but have decreased strongly since the 1980 s due to emission controls (e.g., Lamarque et al., 2010; Granier et al., 2011). Asian emissions have continued to rise under the same period (Ohara et al., 2007). Jonson et al. (2006) showed that the trend in $\mathrm{O}_{3}$ concentrations in Europe cannot be fully explained by changes in European precursor emissions. 
Through intercontinental transport the increasing precursor emissions in Asia could contribute to increasing background levels with at least a strong impact in North America (Vestraeten et al., 2015), whilst the trend in European background $\mathrm{O}_{3}$ seasonal variation could also be affected by the decreases in North American precursor emissions (Fiore et al., 2009; Derwent et al., 2015). Climate also changes over time, causing both changes to the $\mathrm{O}_{3}$-forming potential: biogenic emissions of $\mathrm{O}_{3}$ precursors and deposition processes (Andersson and Engardt, 2010). Variability in climate, such as the North Atlantic Oscillation (NAO), contributes to the variation in $\mathrm{O}_{3}$ concentrations in the upper troposphere through variations both in the stratospheric contribution and in the transport patterns (Gaudel et al., 2015). Although the stratospheric contribution to the $\mathrm{O}_{3}$ concentrations at the surface is generally small (3-5 ppb(v)) in Europe (Lelieveld and Dentener, 2000), it can be a relevant contribution to near-surface $\mathrm{O}_{3}$ in certain areas and time periods (Zanis et al., 2014) and could affect the observed trend in near-surface $\mathrm{O}_{3}$ (e.g., Fusco and Logan, 2003). Despite the large number of studies of tropospheric $\mathrm{O}_{3}$, a number of challenges still remain, such as explaining the near-surface concentration trends (Monks et al., 2015).

Observations in the northern mid-latitudes, taken either at the surface (Oltmans et al., 2006) or from ozonesondes and commercial aircraft (Logan et al., 2012), present the picture of increasing tropospheric $\mathrm{O}_{3}$ concentrations during the second half of the 20th century (Parrish et al., 2012; Cooper et al., 2014). The strong increase in near-surface $\mathrm{O}_{3}$ concentrations until the late 1990s at Mace Head has leveled out to relatively stationary annual values throughout the 2000s (Derwent et al., 2013; Cooper et al., 2014). At Pico Mountain Observatory in the Azores, a decreasing $\mathrm{O}_{3}$ concentration trend was observed during 2001-2011 which was believed to be mainly caused by decreasing precursor emissions in North America (Kumar et al., 2013). Air masses with European origin observed at Mace Head show a decrease in summertime peak $\mathrm{O}_{3}$ concentrations and increase in wintertime, which is believed to be connected to European $\mathrm{NO}_{x}$ policy (Derwent et al., 2013). $\mathrm{O}_{3}$ concentrations observed at European alpine sites and in ozonesonde data (MOZAIC) above European cities have decreased since 1998 with the strongest decrease in summer (Logan et al., 2012).

Several modeling efforts have been conducted to describe the past near-surface $\mathrm{O}_{3}$ concentration development (e.g., Fusco and Logan, 2003; Schultz et al., 2007; Pozolli et al., 2011; Xing et al., 2015). Parrish et al. (2014) present past trends in tropospheric $\mathrm{O}_{3}$ concentrations modeled with three chemistry-climate models and conclude that while there is considerable qualitative agreement between the measurements and the models, there are also substantial and consistent quantitative disagreements. The models capture only $50 \%$ of the change observed during the last 5-6 decades and little of the observed seasonal differences, and the rate of the trends are poorly captured. There are ways forward to improve the description of the trends in models: (1) under- standing the processes and improving the model description of the physics and chemistry for processes of greatest importance in these models, (2) improving the input data quality and (3) incorporating observations in the model by data fusion methods to accurately represent the past statistics in a reanalysis. The first two are important for conducting scenario calculations, whilst the last is an option for producing mappings.

If correctly conducted, data fusion will improve the modeled estimates. If temporal and spatial consistency is not considered, it may however introduce artificial trends. Artificial trends can for example arise from the introduction of new observation sites, which reduce the model bias in the area surrounding the measurement site during the time it is included but not before. Data assimilation, a subset to data fusion (Zhang et al., 2012), is the process by which observations of the real world are incorporated into the model state of a numerical model, in this case into the chemistrytransport model (CTM; Kalnay, 2003; Denby and Spangl, 2010). Advanced data assimilation schemes like the fourdimensional variational technique (4DVAR; e.g., Courtier et al., 1994; Inness et al., 2013) utilize information provided by satellites and propagate this in space and time from a limited number to a wide range of chemical components to provide fields that are physically and chemically consistent with the observations. Inness et al. (2013) performed a reanalysis of global chemical composition, including $\mathrm{O}_{3}$ concentration, for 2003-2010 using advanced data assimilation of satellite observations within the framework of the Monitoring Atmospheric Composition and Climate (MACC) project. They demonstrated improved $\mathrm{O}_{3}$ and $\mathrm{CO}$ concentration profiles for the free troposphere, but biases remained for the lower troposphere. Another reanalysis of near-surface $\mathrm{O}_{3}$ concentrations in Europe, also within the MACC project, was conducted for the period 2003-2012 (Katragkou et al., 2015). In this reanalysis 4DVAR data assimilation was also used to incorporate retrievals from satellites. The data assimilation reduced the bias in near-surface $\mathrm{O}_{3}$ concentrations in most of Europe, and it reproduced the summertime maximum in most parts of Europe, but not the early spring peak in northern Europe. A third global reanalysis using data assimilation of satellite data for 2005-2012 showed improved performance for many chemical species (Miyazaki et al., 2015); however, for the $\mathrm{O}_{3}$ concentrations at the surface, errors remain associated with low retrieval sensitivity in the lower troposphere and gaps in spatial representation between the model and observations. In order to improve surface characteristics, in situ observations of $\mathrm{O}_{3}$ need to be included in the data assimilation.

When restricting the observations to in situ measurements in Europe, the beginning of the time period of the reanalysis can be extended further back in time utilizing simpler variational data analysis techniques. Variational data analysis in two dimensions (2DVAR) and the analytical counterpart optimal interpolation can be used as CPU-efficient diagnostic tools to improve modeled near-surface $\mathrm{O}_{3}$ retrospec- 
tively (e.g., Alpfjord and Andersson, 2015; Robichaud and Ménard, 2014).

The MATCH (Multi-scale Atmospheric Transport and CHemistry) Sweden system (Alpfjord and Andersson, 2015) includes an operational CTM and methods for variational data analysis of atmospheric concentrations in air and precipitation. In this study, the MATCH Sweden system is used to conduct a reanalysis of the hourly near-surface $\mathrm{O}_{3}$ concentrations for Sweden and Norway during the 24-year period 1990-2013 using 2DVAR. We use time-consistent input data to avoid the introduction of artificial trends in the results. In an attempt to understand the trends, we perform model sensitivity analyses and apply the CTM without variational data analysis. This approach brings new knowledge to explain the trends in $\mathrm{O}_{3}$ concentrations found in Sweden.

The aims of this study are as follows:

- to create a state-of-the art, long-term, temporally and spatially consistent reanalysis of hourly near-surface $\mathrm{O}_{3}$ concentrations covering the geographical areas of Sweden and Norway (see Sect. 2);

- to evaluate the performance of the $\mathrm{O}_{3}$ reanalysis of the MATCH Sweden system used in the annual assessment of air quality in Sweden (see Sect. 3.1);

- to investigate trends and extreme values in near-surface $\mathrm{O}_{3}$ in Sweden (see Sect. 3.2) and its implications on health and vegetation (see Sect. 3.4);

- to understand the causes of the change over time, focusing on contributions of emission change, lateral and upper boundary concentrations and meteorological variability (see Sect. 3.3).

\section{Method}

In this study we utilize variational data analysis in order to combine the best qualities of a CTM and long-term measurements to map near-surface $\mathrm{O}_{3}$ concentrations during a long historical time period (1990-2013). We focus our study on Sweden, but also include Norway in the variational data analysis.

For the variational data analysis we use the MATCH Sweden system, which is briefly explained in Sect. 2.1. Here variational analysis in two dimensions is applied, and further details are given in Sect. 2.4. Concentration fields provided by the CTM at each grid point are considered as the "first guess" (background field/prior information) of our "best estimate" of the state of the atmosphere before the introduction of observations (Kalnay, 2003). The method used for the production of the first guess is explained in Sect. 2.2. The selection of measurements that are included in the variational data analysis is important, both to avoid artificial trends in the reanalysis data and in order to select observation sites with corresponding spatial and temporal representations as in the model. We explain our method for the selection of measurements in Sect. 2.3.

One aim of this study is to investigate trends in nearsurface $\mathrm{O}_{3}$ in Sweden. To understand the long-term changes in concentration we try to quantify the causes of change, through model sensitivity analyses, and by applying the MATCH model without variational data analysis. We investigate the respective contributions to the trends by separating the impact on $\mathrm{O}_{3}$ trends of changes in European and local emissions in Sweden, in hemispheric background concentrations (including changes to the top and lateral boundaries) and in meteorology (including changes to biogenic emissions, transport, $\mathrm{O}_{3}$ forming capacity, $\mathrm{O}_{3}$ deposition etc.). The method for this quantification is described in Sect. 2.5. The methods we use for evaluation are given in Sect. 2.6.

\subsection{The MATCH Sweden system}

The MATCH Sweden system is an operational system used for annual assessments of near-surface regional background concentrations in air of $\mathrm{O}_{3}, \mathrm{NO}_{2}$, ammonia $\left(\mathrm{NH}_{3}\right)$ and sulfur dioxide $\left(\mathrm{SO}_{2}\right)$ as well as deposition of sulfur, nitrogen and base cations over Sweden (Alpfjord and Andersson, 2015). The system includes an operational CTM (MATCH; Multiscale Atmospheric Transport and Chemistry; Robertson et al., 1999) and methods for variational data analysis (using 2DVAR) of atmospheric concentrations in air and precipitation. The yearly results from the mapping can be found at www.smhi.se/klimatdata/miljo/atmosfarskemi.

The flow chart in Fig. 1 describes the parts of the MATCH Sweden system that are used in this reanalysis of near-surface $\mathrm{O}_{3}$ concentrations. Explanations are provided in Sect. 2.2 to 2.4. For a description of the whole MATCH Sweden system, see, for example, Alpfjord and Andersson (2015).

\subsection{First guess - model assessment}

The starting point (see Fig. 1) for the two-dimensional retrospective variational data analysis of near-surface $\mathrm{O}_{3}$ is hourly fields of modeled $\mathrm{O}_{3}$, produced by MATCH. The MATCH model includes ozone- and particle-forming photo-chemistry with $\sim 60$ species (Langner et al., 1998; Andersson et al., 2007, 2015). Part of the gas-phase chemical scheme was updated based on Simpson et al. (2012), except for some reaction rates (following the recommendations by the International Union of Pure and Applied Chemistry, IUPAC), and the isoprene chemistry mechanism that was based on an adapted version of the Carter one-product mechanism (Carter, 1996; Langner et al., 1998). A selection of compounds with different ozone-forming potentials is used to represent all hydrocarbons emitted into the atmosphere. The photolysis rates depend on the photolytically active radiation, which is dependent on latitude, time of day, cloud cover, etc. In this study MATCH interpolates the input meteorology and emissions to a domain covering Europe and surrounding ar- 
(a)
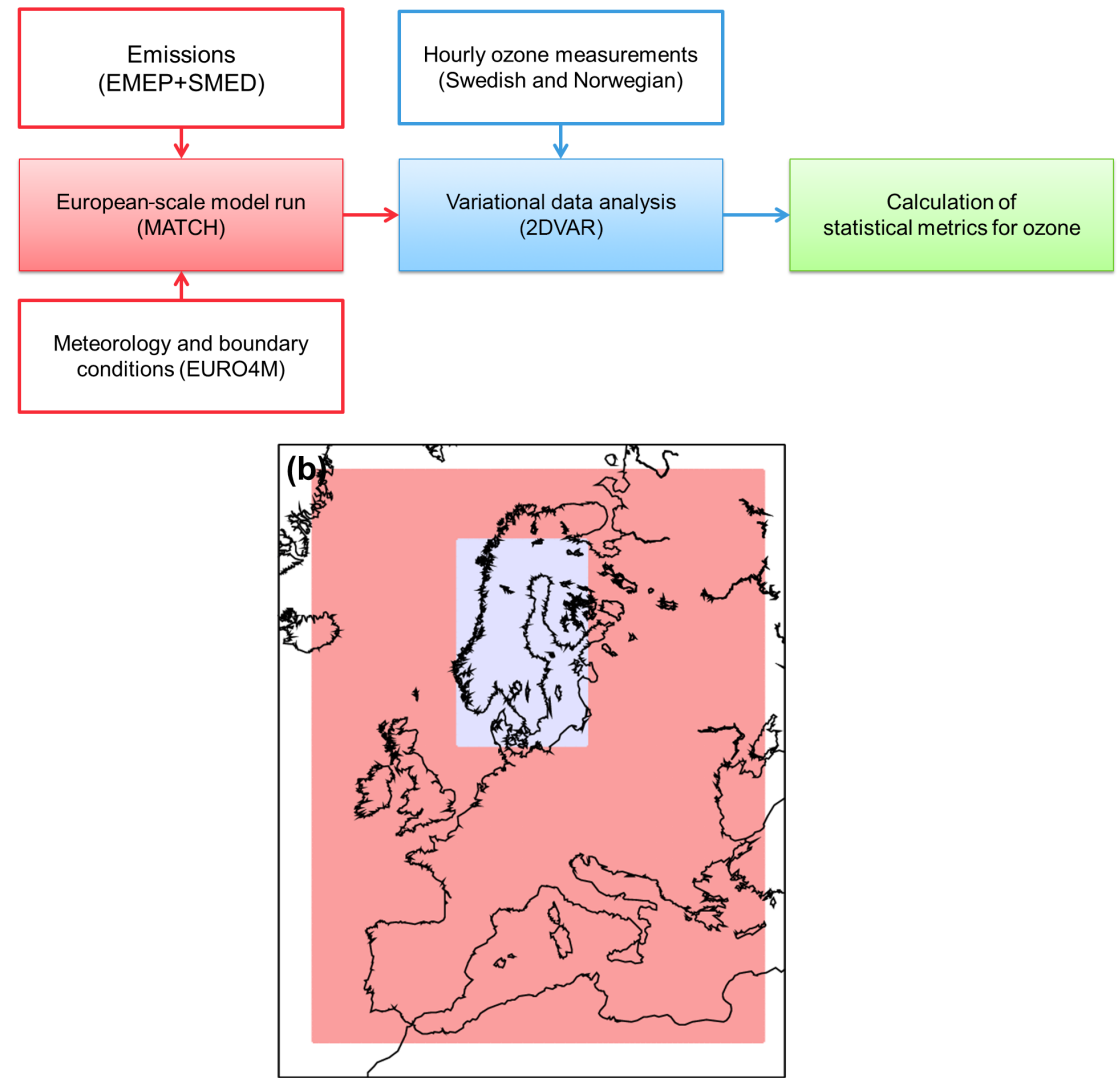

Figure 1. (a) A flow-chart of the relevant part of the MATCH Sweden system for this reanalysis study. (b) The total domain of the European scale model run (pink + light blue) and the domain of the variational data analysis (light blue).

eas with $44 \mathrm{~km}$ grid point spacing. MATCH uses all meteorological model layers for vertical wind calculations, but restricts the calculations of chemistry and transport to the lower troposphere using the vertical levels of the meteorological model from the surface up to ca. $5 \mathrm{~km}$ height, which is the model's standard configuration for pan-European simulations. The selected setup has been demonstrated (e.g., Andersson et al., 2007; Langner et al., 2012a; Markakis et al., 2016) to be adequate for describing near-surface $\mathrm{O}_{3}$ across Europe although trends in stratospheric chemistry or physically driven changes in stratospheric-tropospheric exchanges will likely not be captured.

MATCH is an offline model and thus driven by meteorological data generated externally; as such it is often a challenge to undertake long (multi-decadal) simulations due to non-homogenous input data. Dynamical meteorological models, which provide the three-dimensional meteorology for the offline CTMs, are constantly updated to higher resolutions and more advanced physical schemes. Emission inventories are typically constructed for certain target years and different methods may have been used to compile total emissions and/or the geographical distribution of the emissions. Careless combination of different emission data or meteorology from varying model configurations can introduce artifi- cial secular trends in the modeling of atmospheric pollutants. In this study, we specifically aimed for internally coherent input data, although it led to compromises in, for example, the temporal coverage of the meteorology and the resolution of the gridded pan-European emissions. In the following sections we briefly describe the utilized input data. Further details of MATCH in the present model version and its ability to simulate near-surface $\mathrm{O}_{3}$ can be found in separate publications, for example Markakis et al. (2016), Lacressoniere et al. (2016) and Watson et al. (2015, 2016).

\subsubsection{Meteorology and boundary concentrations}

In the present study we force MATCH with threedimensional meteorology from the numerical weather forecast model HIRLAM. Within the EURO4M-project HIRLAM was run as forecasts from 6-hourly analyses, composed of three-dimensional variational upper-air analyses and optimal interpolation surface analyses (Dahlgren et al., 2016). Lateral and lower (sea surface temperature and sea ice) boundaries were taken from ERA-Interim (Dee et al., 2011). Full three-dimensional model states needed to run MATCH are available from 1979 through February 2014. Under EURO4M, HIRLAM was running on a domain cover- 

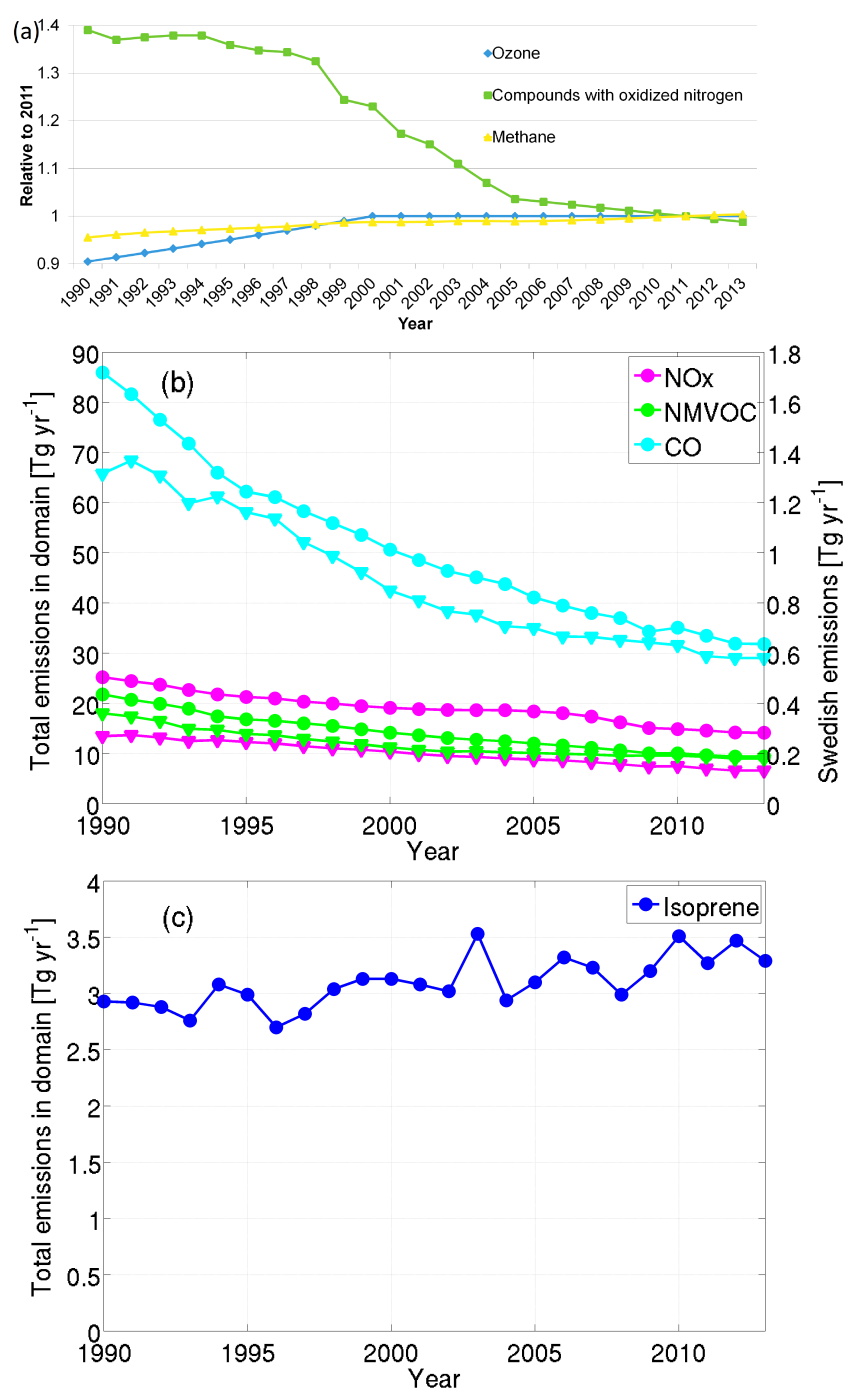

Figure 2. (a) Temporal trend of factors used for scaling boundary concentration of relevant species (based on Engardt et al., 2017). (b) Temporal trend of total domain (circles; left vertical scale) and Swedish (triangles; right vertical scale) annual anthropogenic $\mathrm{O}_{3}$ precursor emissions utilized by MATCH from 1990 to 2013. Emissions of nitrogen oxides $\left(\mathrm{NO}_{x}\right)$, non-methane volatile organic compounds (NMVOC) and carbon monoxide $(\mathrm{CO})$ are indicated by different colors (cf. legend); emissions of sulfur oxides $\left(\mathrm{SO}_{x}\right)$ and ammonia $\left(\mathrm{NH}_{3}\right)$ are excluded from the panel. (c) Temporal trend of total domain biogenic isoprene emissions.

ing Europe and northern Africa with $22 \mathrm{~km}$ grid point spacing and 60 vertical layers from the surface to $10 \mathrm{hPa}$.

Although the present study focuses on Sweden, it is necessary to realistically describe the fluxes of $\mathrm{O}_{3}$ and its precursors from continental Europe and further afield. Hemispheric background concentrations of all species for the modeled year 2000 are similar to the ones used by Andersson et al. (2007). As in Andersson et al. (2007), boundary values representative of the average concentrations at the lateral and top boundaries of relevant species are interpolated spatially with a monthly temporal resolution. Boundary concentrations of $\mathrm{O}_{3}$, oxidized nitrogen and methane are furthermore scaled to mimic observed changes in the hemispheric background during the period 1990 through 2013 following the work of Engardt et al. (2017); see Fig. 2a. Note that the hemispheric background ozone concentrations are assumed constant from 2000 onwards following recent assessments of the evolution of near-surface ozone in Europe (e.g., Cooper et al., 2014). CO and NMVOC boundaries are held constant throughout the simulation. The same factor is used for all months of the respective year, although most species also undergo a seasonal cycle in the boundary concentrations used by MATCH (see Supplement Fig. S1).

\subsubsection{Emissions}

The version of MATCH utilized in this study needs anthropogenic emissions of sulfur $\left(\mathrm{SO}_{2}\right.$ and sulfate), nitrogen oxides ( $\mathrm{NO}$ and $\mathrm{NO}_{2}$ ), carbon monoxide $(\mathrm{CO})$, non-methane volatile organic compounds (NMVOCs) and $\mathrm{NH}_{3}$. The model uses annually accumulated values for each species, which are distributed with different temporal or vertical profiles based on species and sectors.

For countries outside Sweden (as well as international shipping) we utilize the gridded $(50 \mathrm{~km} \times 50 \mathrm{~km})$ annual data available at the European Monitoring and Evaluation Programme (EMEP) website (Hjellbrekke and Solberg, 2015; http://www.emep.int; downloaded 23 June 2015). All emission data were split into congruent $5 \mathrm{~km} \times 5 \mathrm{~km}$ cells where we replaced the coarse-resolution data over Sweden with the original emission data from SMED (Svensk miljöemissionsdata; http://www.smed.se; $1 \mathrm{~km} \times 1 \mathrm{~km}$ converted to $5 \mathrm{~km} \times 5 \mathrm{~km}$ cells in EMEP's geometry). National totals from SMED are very similar to the national totals available in the EMEP database, but our methodology enables higher-resolution emission data over Sweden. The gridded $5 \mathrm{~km} \times 5 \mathrm{~km}$ emission data were interpolated to MATCH's $44 \mathrm{~km}$ resolution domain during the simulations. Emissions of biogenic isoprene are calculated online in MATCH following the E-94 isoprene emission methodology proposed by Simpson et al. (1995).

Both the total domain and Swedish national anthropogenic $\mathrm{O}_{3}$ precursor emissions decrease strongly over the period 1990-2013 (see Fig. 2b). The total domain anthropogenic precursor emissions decrease on average ${ }^{1}$ by 1.8 , 2.4, $2.6 \% \mathrm{yr}^{-1}$ during 1990-2013 for $\mathrm{NO}_{x}$, NMVOCs and $\mathrm{CO}$, respectively, whereas biogenic isoprene emissions (calculated online by MATCH) increase by $0.8 \% \mathrm{yr}^{-1}$ according to our simulations (see Fig. 2c). The national Swedish emissions decrease by similar amounts $\left(2.4,2.1\right.$ and $\left.2.9 \% \mathrm{yr}^{-1}\right)$. The Swedish contribution to the total domain emissions is

\footnotetext{
${ }^{1}$ The trend is calculated by linear regression over the period 1990-2013 and related to the 1990 emission level.
} 


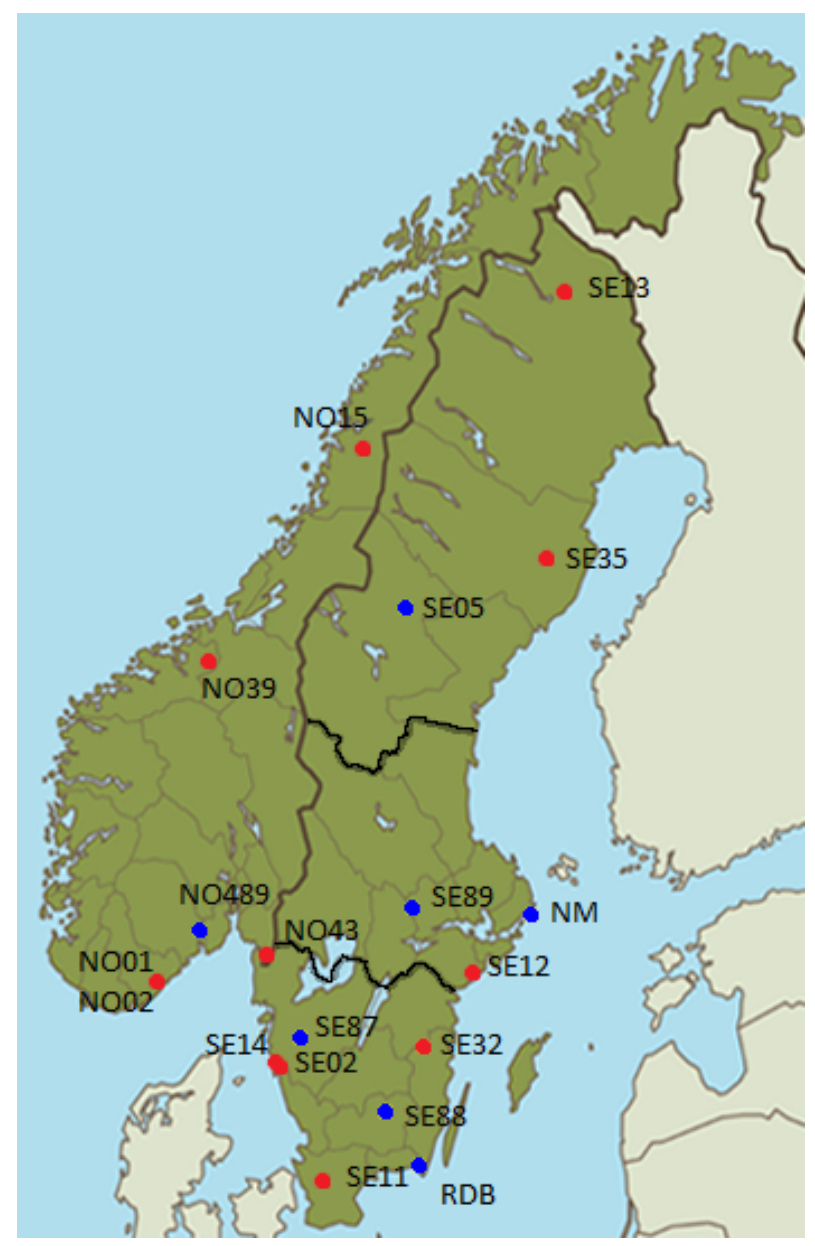

Figure 3. Instrumentation sites for hourly near-surface ozone concentration observations in Sweden and Norway, which are used in the variational analysis. Red circles: sites with full data coverage. Blue circles: sites with restricted data coverage. The subdivision of Sweden into three regions (north, central and south) follows county borders, as indicated by the thick black lines.

$1.0 \%$ for $\mathrm{NO}_{x}$ and $1.7 \%$ for NMVOCs and $\mathrm{CO}$ on average, with a slight decrease in the relative Swedish contribution over the period for $\mathrm{NO}_{x}\left(0.01 \% \mathrm{yr}^{-1}\right)$, and a slight increase for NMVOCs and CO (0.01 and $0.003 \% \mathrm{yr}^{-1}$, respectively). The amount and spatial distribution of the emissions is updated each year.

\subsection{Measurements}

Figures 3 and 4 summarize the observations of hourly $\mathrm{O}_{3}$ concentrations used in the variational analysis and the corresponding hourly data coverage per year in the period 1990-2013. The Swedish observations were delivered by the Swedish data host (at the time, 1 July 2017, Swedish Environmental Institute, IVL). The Norwegian observations were extracted from EBAS (http://ebas.nilu.no; extracted on 6 July 2017). All sites except Norr Malma and Rödeby are classified as regional background measurement sites by EMEP (http://www.nilu.no/projects/ccc/emepdata.html; Hjellbrekke and Solberg, 2015). Norr Malma is located ca. $70 \mathrm{~km}$ northeast of Stockholm and is considered a regional background measurement site by Stockholm Air and Noise (http://slb.nu), who are responsible for the site. Rödeby is located $10 \mathrm{~km}$ north of the small town Karlskrona, and is considered a rural location (Swedish EPA, T. Kyrklund, personal communication, 2015). The sites included are all instrumentation sites, where $\mathrm{O}_{3}$ is measured continuously and reported with hourly temporal resolution. The retrospective variational data analysis is conducted at an hourly resolution, which means that measurements with a coarser time resolution, such as diffusive samplers, are not included in the variational technique. Two measurement data sets were compiled (see Table 1):

- The first set includes data from all available instrumentation sites in Sweden, and a selection in Norway based on data availability, quality and location. These are all the red and blue sites in Figs. 3 and 4 also including years where the data capture is lower than $80 \%$. The reanalysis based on these measurement data is called ALL.

- The second data set includes data from instrumentation sites for which the data coverage exceeds $80 \%$ for at least 23 out of the 24 years. These are the red sites in Figs. 3 and 4. The reanalysis based on these measurement data is called LONGTERM. Råö is seen as the replacement for the site Rörvik, and therefore these sites form a pair, which is included in this data set. Birkenes I was replaced by Birkenes II in 2009, and the two sites were run in parallel for a few years. We choose to include Birkenes II from 2010 and onwards. The reason for the change of site location is that Birkenes I was influenced by local effects (NILU, S. Solberg, personal communication, 2015). The inclusion of these two sites could introduce an abrupt change in the reanalysis, but since it is outside the main focus area (Sweden) and mainly during night we choose to include the site in the LONGTERM reanalysis.

The two measurement data sets are input to two otherwise similar variational data analyses. The ALL reanalysis is our best estimate of gridded near-surface $\mathrm{O}_{3}$ over Sweden for a given time. The LONGTERM reanalysis is used for trend and statistical analyses. We return to whether these reanalyses differ in Sect. 3.1.

\subsection{Variational data analysis}

The spatial analysis problem can be formulated as how to best distribute observational information at a discreet number of locations to a spatially consistent field. We have adopted the 2DVAR approach, which includes a modeled background 


\begin{tabular}{|c|c|c|c|c|c|c|c|c|c|c|c|c|c|c|c|c|c|c|c|c|c|c|c|c|c|}
\hline & & 19901 & 1991 & 1992 & 1993 & 1994 & 1995 & 1996 & \begin{tabular}{|l|}
1997 \\
\end{tabular} & 1998 & 19992 & \begin{tabular}{l|l}
2000 & 2 \\
\end{tabular} & 2001 & 2002 & \begin{tabular}{|l|l|}
20032 & \\
\end{tabular} & 2004 & 2005 & 2006 & 2007 & 2008 & \begin{tabular}{l|l}
2009 & 2 \\
\end{tabular} & 20102 & 2011 & 2012 & 2013 \\
\hline SE13 & Esrange & 30 & & & & & & & & & & & & & & & & & & & & & & & \\
\hline SE35 & Vindeln & & & & & & & & & & & & & & & & & & & & & & & & \\
\hline SE05 & Bredkälen & & & & & & & & & & & & & & & 58 & & & & & & & & & \\
\hline SE89 & Grimsö & & & & & & & & & & & 42 & & & & 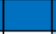 & & & & & & & & & \\
\hline NM & Norr Malma & & & & & & & & & & & & & & & & 0.01 & & & & & & & & \\
\hline SE12 & Aspvreten & & & & & & & & & & & & & & & & & & & & & & & & \\
\hline SE32 & Norra Kvill & & & & & & & & & & & & & & & & & & & & & & & & \\
\hline SE88 & Asa försökspark & & & & & & 50 & & & & 75 & & & & & 45 & & & & & & & & 58 & \\
\hline SE87 & Östad & & & & & & & & & & & - & 47 & 34 & 20 & 45 & 49 & 50 & 50 & 50 & 50 & 50 & 49 & 50 & \\
\hline SE02 & Rörvik & & & & & & & & & & & & & & & & & & & & & & & & \\
\hline SE14 & Råó & & & & & & & & & & & & & & & & & & & & & & & & \\
\hline RDB & Rödeby & & & & & & & & & & & & & & & & & & & & & & & & 5 \\
\hline SE11 & Vavihill & & & & & & & & & & & & & & & & & & & & & & & & \\
\hline NO15 & Tustervatn & & & & 73 & & & & & & & & & & & & & & & & & & & & \\
\hline NO39 & Kårvatn & & & & & & & & & & & & & & & & & & & & & & & & \\
\hline NO489 & Haukenes & & 47 & 22 & 42 & 51 & 51 & 53 & 55 & 49 & 49 & 51 & 39 & 53 & 53 & & & 40 & & 67 & & & 72 & & \\
\hline NO43 & Prestebakke & & & 65 & & & & & & & & & & & & & & & & & & & & & \\
\hline NO01 & Birkenes I & & & & & & & & & & & & & & & & & & & & & & & & \\
\hline NO02 & Birkenes || & & & & & & & & & & & & & & & & & & & & & & & & \\
\hline
\end{tabular}

Figure 4. Data availability at instrumentation sites for hourly near-surface ozone concentration observations in Sweden and Norway. Red squares: years with at least $80 \%$ annual data for sites with full data coverage (see also Fig. 3). Light red: sites with < $80 \%$ annual data (data capture indicated in square) for sites with full coverage. Blue and light blue squares: as for the red squares, but for sites with restricted data coverage. White squares: no observations are available for that year and site. The LONGTERM reanalysis includes the red measurement sites; the ALL reanalysis includes both red and blue.

field (from a CTM simulation, first guess) combined with available in situ observations (Robertson and Kahnert, 2007), as indicated in Fig. 1. With this method the error estimates of both the background field and the observations play a central role. The observational errors are assumed independent and uncorrelated, while the background errors have spatial correlations that form a background error matrix. The solution is found by the best combination of the background field and observations given their respective error estimates. This can be described as a variational problem, defined by a cost function,

$$
\begin{aligned}
J(x) & =1 / 2\left[\boldsymbol{x}-\boldsymbol{x}^{\mathrm{b}}\right]^{T} \mathbf{B}^{-1}\left[\boldsymbol{x}-\boldsymbol{x}^{\mathrm{b}}\right] \\
& +1 / 2[\boldsymbol{y}-\mathbf{H}(x)]^{T} \mathbf{O}^{-1}[\boldsymbol{y}-\mathbf{H}(x)],
\end{aligned}
$$

where $x$ is the state to be found (the reanalysis), $x^{\mathrm{b}}$ the background state (our first guess), $\boldsymbol{y}$ the vector of observations, $\mathbf{H}$ is the observation operator and $\mathbf{B}$ and $\mathbf{O}$ are the error covariance matrices of the background field and the observations, respectively. In order to find the optimal solution the cost function is stepwise minimized by a variational method, starting with $x=x^{\mathrm{b}}$, and ending with the state $x$, which represents the optimal balance between the two terms. During the process the co-variances in the $\mathbf{B}$ matrix acts to extrapolate the observational information in space.

We restrict our study to reanalyze near-surface $\mathrm{O}_{3}$ on the regional background scale, which means we only include regional background measurement sites. We also restrict our study to 2DVAR, rather than using higher-dimensional variational analysis. The background covariance matrix is modeled in a simplified fashion with a constant background error, 20 times larger than the observation error, and Gaussian spatial correlations with a length scale of $1000 \mathrm{~km}$. This implies a strong weight towards the observations and assumes a rather large horizontal influence of the observations.

The variational data analysis was conducted on a $22 \mathrm{~km}$ resolution grid with hourly temporal resolution, combining the modeled first guess for near-surface $\mathrm{O}_{3}$ (the MATCH base case scenario, MFG in Table 1) and regional background measurements. Two 24-year reanalyses were formed using the two different sets of hourly measurement described in Sect. 2.3 (ALL and LONGTERM in Table 1). If an included measurement site was lacking an observation for a specific hour, the site was excluded from the variational data analysis for that specific hour.

The resulting spatially resolved hourly $\mathrm{O}_{3}$ data are used to form annual and seasonal statistical metrics for $\mathrm{O}_{3}$, such as the mean value and the maximum $1 \mathrm{~h}$ mean value, and annual policy- and impact-related metrics (see Fig. 1). We analyze these annual and seasonal data for the 1990-2013 mean, trend and extreme values in Sect. 3.2 (annual/seasonal mean and maximum) and Sect. 3.4 (health and vegetation impact metrics).

\subsection{Understanding the trends}

We also include a quantification of the causes to the trend in near-surface $\mathrm{O}_{3}$ concentration. For this investigation we conduct model simulations with MATCH, excluding variational data analysis. We investigate the respective contributions to the modeled total trend due to the following:

a. Change in emissions, which is separated between (1) Swedish anthropogenic emissions (SE emis) and (2) full 
Table 1. (a) Model calculations and scenarios, all covering the years 1990-2013, including the first guess to the retrospective variational data analysis and base case to the sensitivity simulations (MFG), two reanalysis data sets (LONGTERM and ALL) and sensitivity scenarios (MFD, MSE, MBC and MMET). (b) Formation of contributions to the linear trend over the period 1990-2013 from the sensitivity simulations (a).

$$
\text { Scenario/data set Description }
$$

(a)

\begin{tabular}{ll}
\hline MFG & MATCH base case simulation and first guess used as input to the reanalyses. \\
\hline LONGTERM & $\begin{array}{l}\text { Reanalysis data set of hourly near-surface ozone concentration covering Sweden and Norway based on (1) the } \\
\text { MFG European MATCH simulation and (2) selected hourly near-surface ozone measurements in Sweden and } \\
\text { Norway, based on temporal coverage of the measurement sites. Optimal for trend analyses. Analyzed and } \\
\text { presented in Sect. 3. }\end{array}$ \\
\hline
\end{tabular}

ALL Reanalysis data set of hourly near-surface ozone concentration covering Sweden and Norway based on (1) the MFG European MATCH simulation and (2) all available Swedish hourly ozone measurements and a selection of the Norwegian (as in LONGTERM). Not used for trend analyses in this study, but best estimate for the hourly near-surface ozone concentration in Sweden at any point in time.

\begin{tabular}{ll}
\hline MFD & $\begin{array}{l}\text { MATCH sensitivity simulation where the full domain anthropogenic emissions are kept constant from year to } \\
\text { year, set to the level of } 2011 .\end{array}$ \\
\hline MSE & $\begin{array}{l}\text { MATCH sensitivity simulation where the Swedish anthropogenic emissions are kept constant from year to year, } \\
\text { set to the level of } 2011 .\end{array}$ \\
\hline MBC & $\begin{array}{l}\text { MATCH sensitivity simulation where the top and lateral boundaries for all species are kept constant from year } \\
\text { to year, set to the level of } 2011 .\end{array}$ \\
\hline MMET & MATCH sensitivity simulation where the meteorology is kept constant, using the meteorological year 2011. \\
\hline (b) & Contribution to the trend caused by the change in anthropogenic Swedish emissions, calculated as the model \\
seenario difference: MFG-MSE. \\
\hline FD emis & $\begin{array}{l}\text { Contribution to the trend caused by the change in full domain anthropogenic, non-Swedish emissions, } \\
\text { calculated as the model scenario difference: (MFG-MFD)-(MFG-MSE). }\end{array}$ \\
\hline emis & $\begin{array}{l}\text { Contribution to the trend caused by the change in full domain anthropogenic emissions, calculated as the model } \\
\text { scenario difference: MFG-MFD. Used only for the base year sensitivity investigation. }\end{array}$ \\
\hline bound & $\begin{array}{l}\text { Contribution to the trend caused by the change in lateral and upper boundaries, calculated as the model scenario } \\
\text { difference: MFG-MBC. }\end{array}$ \\
\hline meteo & Contribution to the trend caused by the variation in meteorology, calculated as the model scenario difference: \\
MFG-MMET.
\end{tabular}

domain (see Fig. 1b) non-Swedish anthropogenic emissions (FD emis).

b. Change in lateral and upper boundaries (bound).

c. Change in meteorology, including online modeled biogenic isoprene emissions (meteo).

Four sensitivity simulations are conducted, in which each of the four listed factors are kept constant at their level in 2011. The respective contributions presented in Sect. 3.3 are formed through the following sequence: (1) calculation of gridded metrics (focusing on monthly $1 \mathrm{~h}$ maximum, monthly mean and annual $1 \mathrm{~h}$ percentile levels); (2) calculation of secular gridded trends over the monthly or annual metrics; (3) calculation of regional (north, central, south; see Fig. 3) mean of the secular trends; and (4) calculation of the difference between the regional mean trend in MFG and the corresponding sensitivity simulation. All model simulations and scenarios are described in Table 1a. The method of forming the contributions from these simulations is shown in Table $1 \mathrm{~b}$.

There are three critical points in the investigation of the causes of the trend: first, this quantification methodology assumes linearity, whereas the sum of contributions (SUM) is not necessarily equal to the trend in the MFG simulation. If they are not equal, it means that the simulations are nonadditive. This could occur when changes to mixtures of com- 
plex chemistry, weather situations and emissions take place, or as a numeric effect in the model. For this reason we compare the sum of the trend in the estimated contributions to the MFG trend. Second, our methodology quantifies the contributions to the trend in the MFG simulation, which may differ from the reanalyzed trend. Thus we will compare the reanalyzed trend and the MFG trend to make sure the base case simulation does not deviate too strongly from the reanalysis results. If the deviation is large, i.e., the modeled trend is far from the observed, it means that the MFG simulation is non-representative. Such discrepancies could arise from over-sensitivity in MATCH to one process and insensitivity to another, compared to the real world, or imperfections/artificial trends in the input data such as erroneously estimated emissions or erroneous assumptions on the trend in hemispheric background concentrations. If either is true (non-additive or non-representative) for the trend in a specific metric, then our method cannot be used to explain that specific trend. Third, the attribution may be sensitive to the chosen base year. Sensitivity simulations using 1990 as base year instead of 2011 are also conducted, to investigate the robustness of the results. As investigating all 24 years as base years would take too much computational effort, we choose 1990 as it differs from 2011 both for European emissions and climatologically. ${ }^{2}$ If the contributions to the trend differ too much between the base years 1990 and 2011 then the results are not robust. If they are similar it is not a guarantee that the results are robust but it is an indication. The contributions with 1990 as base year are formed in the same way as for the 2011 sensitivity runs. The contributions due to change in top and lateral boundaries (bound) and variations in meteorology are included in the same manner, while we compare the total footprint of the change in emissions, i.e., the sum of FD emis and SE emis (emis) rather than the two parts.

\subsection{Evaluation}

We evaluate two aspects of the reanalysis. The first is an independent evaluation for a single year with focus on the variational data analysis method. The second is an evaluation of the simulated near-surface $\mathrm{O}_{3}$ concentration trend over the 24-year period and our ability to explain the causes of the trend.

For an independent evaluation of the variational data analysis method we conduct a cross validation at the included Swedish measurement sites. In this method we exclude one measurement site at a time from the variational data analysis, and evaluate the results at the excluded location. This means we conduct one 2DVAR simulation for each considered measurement site. Due to the large amount of computation involved we evaluate only one of the years using this method. We choose the year 2013, which is when the

\footnotetext{
${ }^{2}$ The NAO index was high in early winter 1990 and low in 2011, whereas the summer index was positive but close to 0 in 1990 and negative in 2011.
}

data coverage is the largest. This means that we also have the opportunity to investigate whether we see any difference in performance between the reanalysis with the larger number of measurement sites (ALL) and the long-term reanalysis (LONGTERM). The evaluation metrics used here are mean value (mean), standard deviation $(\sigma)$, model mean bias normalized by the observed mean (\%bias), Pearson correlation coefficient $(r)$ and the root mean square error (RMSE); see Supplement Sect. S1.

For the evaluation of the long-term trend we focus on the three critical points raised in the previous section: (1) the additivity of the trend in the contributions as compared to the trend in $\mathrm{O}_{3}$ concentrations from the MFG simulation, (2) whether the MFG trend is representative of the $\mathrm{O}_{3}$ concentration trend in the LONGTERM reanalysis results and (3) whether the contributions to the secular trend are sensitive to base year. We focus this investigation on 11 different percentiles of hourly mean $\mathrm{O}_{3}$ concentrations, for an estimate of the scores at different concentration levels. We focus specifically on averages over the three Swedish regions north, central and south (see Fig. 3), to investigate whether there is any variation in performance in Sweden.

Additional evaluation and comparisons of the temporal variation over the whole period is included in the Supplement for the two reanalyses LONGTERM and ALL, the MATCH simulation MFG and observed annual mean (see Supplement Sect. S2, Figs. S2-S4 and Table S1).

\section{Results}

\subsection{The performance of the model simulations and reanalyses}

Before turning to the evaluation results, we investigate whether the two ozone reanalyses differ. We do this by comparing time series of annual $\mathrm{O}_{3}$ metrics for the two data sets. The investigation is presented in the Supplement and shows deviations in the later years as the number of sites in the ALL data set increases beyond the sites included in the LONGTERM data set (see Sect. S3 and Figs. S2-S4). The deviation in annual mean near-surface $\mathrm{O}_{3}$ concentrations is larger than for annual maximum $1 \mathrm{~h}$ mean given that many of the newer sites are sensitive to nighttime inversions. Due to the visible deviation in results, we use the LONGTERM for the trend and statistical analyzes in the paper, whereas both are used for the evaluation of the 2DVAR method in this section. Both are included in the method evaluation because the evaluation scores may be dependent on the density and specific locations of the measurement sites. The ALL data set is to be used as a best estimate of geographically resolved near-surface $\mathrm{O}_{3}$ concentrations for Sweden for a subset period within the full period 1990-2013.

In Table 2 we show the evaluation statistics from the validation of hourly and daily maximum of hourly mean near- 
Table 2. Evaluation of modeled hourly and daily maximum of $1 \mathrm{~h}$ mean near-surface ozone concentrations in 2013 at Swedish observation sites. Mean value (mean), standard deviation $(\sigma)$, model mean bias normalized by the observed mean (\%bias), Pearson correlation coefficients $(r)$ for data including at least 10 pairs, the root mean square error (RMSE) and number of observed hours/days* at the sites. The evaluation includes the reanalyzed data sets ALL and LONGTERM, where ALL is evaluated at the 12 Swedish sites included in that simulation, and LONGTERM is evaluated at the 6 Swedish sites included in that simulation (see Fig. 4). For each of these data set evaluations we include the observation-dependent reanalysis (2DVAR), the observation-independent cross validation of the reanalysis (cross) and the MATCH base case simulation (MFG). The top half of the table shows the temporal performance (spatial mean of evaluation statistics; see Supplement Sect. S1). The bottom half of the table shows spatial performance (spatial statistics of annual means; see Sect. S1).

\begin{tabular}{|c|c|c|c|c|c|c|c|}
\hline \multirow[b]{2}{*}{ Hourly mean } & & \multicolumn{6}{|c|}{ Spatial mean of evaluation statistics } \\
\hline & & $\begin{array}{r}\text { mean } \\
(\operatorname{ppb}(\mathrm{v}))\end{array}$ & $\begin{array}{r}\mathrm{SD} \\
(\mathrm{ppb}(\mathrm{v}))\end{array}$ & $\begin{array}{r}\text { \%bias } \\
(\%)\end{array}$ & $r$ & $\begin{array}{r}\text { RMSE } \\
(\mathrm{ppb}(\mathrm{v}))\end{array}$ & \#hours \\
\hline \multirow[t]{4}{*}{ ALL } & obs & 30.9 & 11.0 & & & & 8760 \\
\hline & MFG & 31.1 & 9.4 & 1.4 & 0.67 & 8.8 & \\
\hline & cross & 30.6 & 9.9 & -0.3 & 0.76 & 8.0 & \\
\hline & 2DVAR & 30.8 & 11.1 & -0.6 & 0.94 & 3.5 & \\
\hline \multirow[t]{4}{*}{ LONGTERM } & obs & 32.6 & 10.5 & & & & 8760 \\
\hline & MFG & 31.2 & 9.7 & -3.3 & 0.67 & 8.7 & \\
\hline & cross & 32.2 & 9.3 & -0.1 & 0.72 & 8.5 & \\
\hline & 2DVAR & 32.6 & 10.7 & 0.2 & 0.97 & 2.7 & \\
\hline Daily maximum & & $\begin{array}{r}\text { mean } \\
(\mathrm{ppb}(\mathrm{v}))\end{array}$ & $\begin{array}{r}\text { SD } \\
(\mathrm{ppb}(\mathrm{v}))\end{array}$ & $\begin{array}{r}\text { \%bias } \\
(\%)\end{array}$ & $r$ & $\begin{array}{r}\text { RMSE } \\
(\mathrm{ppb}(\mathrm{v}))\end{array}$ & \#days \\
\hline \multirow[t]{4}{*}{ ALL } & obs & 39.4 & 8.7 & & & & 365 \\
\hline & MFG & 37.7 & 7.6 & -4.3 & 0.79 & 5.8 & \\
\hline & cross & 38.3 & 7.9 & -2.6 & 0.83 & 5.2 & \\
\hline & 2DVAR & 39.5 & 8.5 & 0.3 & 0.97 & 1.4 & \\
\hline \multirow[t]{4}{*}{ LONGTERM } & obs & 40.0 & 8.7 & & & & 365 \\
\hline & MFG & 37.8 & 8.0 & -5.6 & 0.79 & 6.0 & \\
\hline & cross & 38.7 & 7.9 & -3.3 & 0.81 & 5.6 & \\
\hline & 2DVAR & 40.4 & 8.9 & 1.0 & 1.00 & 0.8 & \\
\hline \multicolumn{8}{|c|}{ Spatial statistics of annual means } \\
\hline Annual mean & & $\begin{array}{r}\text { mean } \\
(\mathrm{ppb}(\mathrm{v}))\end{array}$ & $\begin{array}{r}\mathrm{SD} \\
(\mathrm{ppb}(\mathrm{v}))\end{array}$ & $\begin{array}{r}\text { \%bias } \\
(\%)\end{array}$ & $r$ & $\begin{array}{r}\text { RMSE } \\
(\mathrm{ppb}(\mathrm{v}))\end{array}$ & \#stns \\
\hline \multirow[t]{4}{*}{ ALL } & obs & 30.9 & 2.5 & & & & 12 \\
\hline & MFG & 31.1 & 1.2 & 0.6 & 0.21 & 3.0 & \\
\hline & cross & 30.6 & 1.8 & -1.0 & 0.11 & 3.5 & \\
\hline & 2DVAR & 30.8 & 2.8 & -0.5 & 0.98 & 0.7 & \\
\hline \multirow[t]{4}{*}{ LONGTERM } & obs & 32.6 & 2.2 & & & & 6 \\
\hline & MFG & 31.2 & 1.0 & -4.1 & $\mathrm{X}$ & 3.4 & \\
\hline & cross & 32.2 & 1.6 & -1.2 & $\mathrm{X}$ & 4.3 & \\
\hline & 2DVAR & 32.6 & 2.2 & 0.2 & $X$ & 0.2 & \\
\hline $\begin{array}{l}\text { Annual mean } \\
\text { of daily } \\
\text { maximum }\end{array}$ & & $\begin{array}{r}\text { mean } \\
(\mathrm{ppb}(\mathrm{v}))\end{array}$ & $\begin{array}{r}\mathrm{SD} \\
(\mathrm{ppb}(\mathrm{v}))\end{array}$ & $\begin{array}{r}\% \text { bias } \\
(\%)\end{array}$ & $r$ & $\begin{array}{r}\text { RMSE } \\
(\mathrm{ppb}(\mathrm{v}))\end{array}$ & \#stns \\
\hline \multirow[t]{4}{*}{ ALL } & obs & 39.4 & 1.3 & & & & 12 \\
\hline & MFG & 37.7 & 1.2 & -4.4 & 0.43 & 2.5 & \\
\hline & cross & 38.3 & 1.6 & -2.7 & 0.31 & 2.3 & \\
\hline & 2DVAR & 39.5 & 1.6 & 0.3 & 0.90 & 1.0 & \\
\hline \multirow[t]{4}{*}{ LONGTERM } & obs & 40.0 & 1.6 & & & & 6 \\
\hline & MFG & 37.8 & 1.4 & -5.7 & $\mathrm{X}$ & 2.9 & \\
\hline & cross & 38.7 & 2.0 & -3.4 & $\mathrm{X}$ & 2.7 & \\
\hline & 2DVAR & 40.4 & 1.6 & 1.0 & $X$ & 0.4 & \\
\hline
\end{tabular}

* A daily data coverage of $75 \%(>18 \mathrm{~h})$ is required to include the observed daily maximum as a valid observation. 

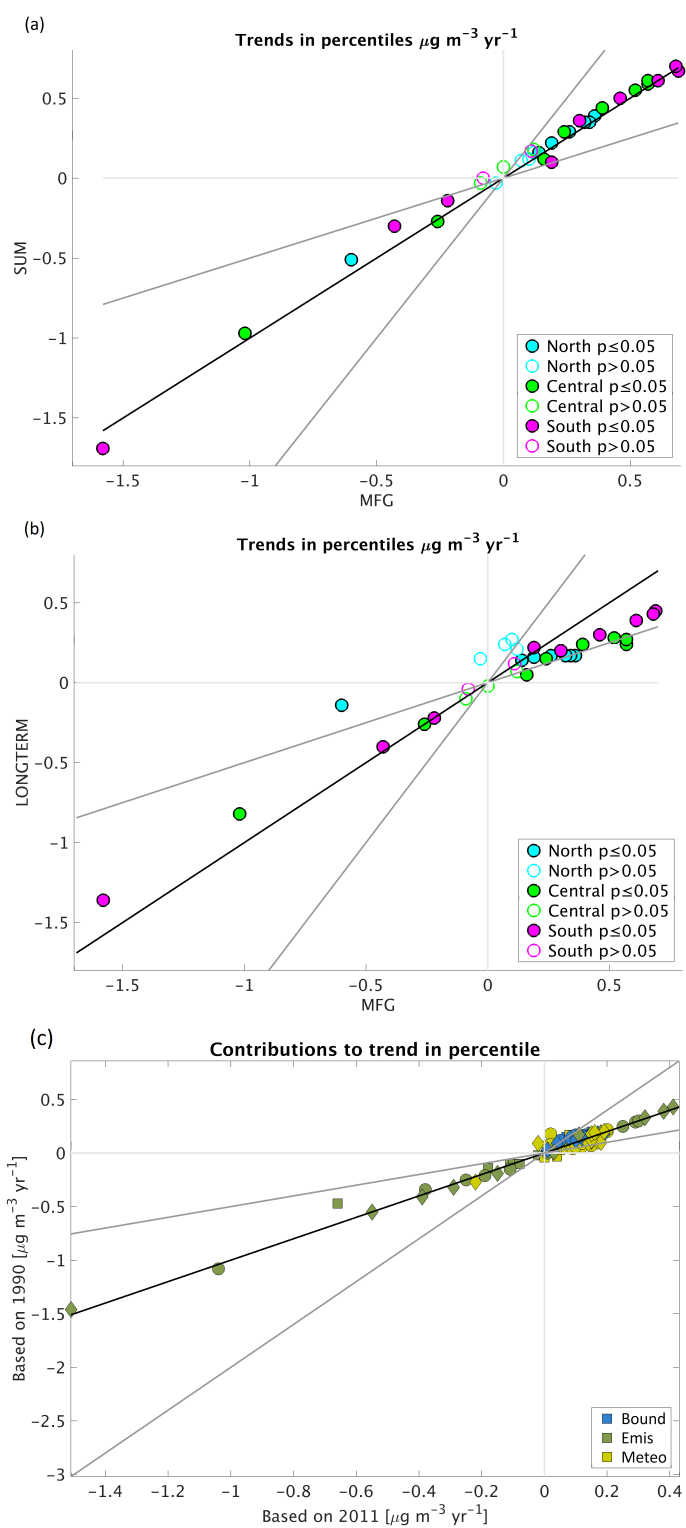

Figure 5. (a, b) Temporal trends in annual percentiles of hourly mean near-surface ozone (levels: $0,2,5,10,25,50,75,90,95,98$ and 100; see Table S2) averaged for the three regions: north (blue), central (green) and south (magenta) for the sum of the contributions to the trend (SUM) vs. the MATCH model simulation MFG (a) and the reanalysis LONGTERM vs. the MATCH model simulation MFG (b). Filled circles indicate significant trends $(p \leq 0.05)$ in the MFG simulation, whereas non-significant MFG trends $(p>0.05)$ are indicated by an empty circle. (c) Sensitivity in contributions to the secular trends in regionally (north: squares; central: circles; south: diamonds) averaged annual percentiles (levels: $0,2,5,10$, $25,50,75,90,95,98$ and 100) of hourly near-surface $\mathrm{O}_{3}$ over the period 1990-2013 due to choice of base year (1990 vs. 2011). Modeled contributions to the near-surface ozone trend due to change in top and lateral boundaries of relevant species (dark yellow, bound), change in full domain emissions (blue, SE emis + FD emis) and variation in meteorology (light yellow, meteo). 1:1 line in black, factor 2 lines in dark grey. surface $\mathrm{O}_{3}$ in 2013. The near-surface $\mathrm{O}_{3}$ concentrations from the MFG simulation compare well with observations, and the 2DVAR technique leads to improvements. The spatially averaged correlation coefficient of hourly near-surface $\mathrm{O}_{3}$ concentrations (see Sect. S1 increases from 0.67 when comparing the MFG $\mathrm{O}_{3}$ concentrations to observations, to 0.76 when comparing the ALL reanalysis independently to observations through a cross validation (Table 2). The \%bias decreases from 1.4 to -0.3 and the RMSE is also improved in the independent evaluation of the ALL reanalysis. Similar improvements are also obtained when using fewer measurements (LONGTERM, Table 2), showing that the method is stable with the number of measurement sites. The cross validation spatial error (RMSE) is however larger than that obtained when evaluating the MFG simulation against independent observations, where the cross validation results indicates that the 2DVAR reduces the quality of the annual mean spatial variation in 2013. The evaluation of the daily maximum generally shows better correlation but slightly larger bias than the evaluation of the hourly mean. The spatial correlation is also worse in the cross validation compared to the MFG, but the spatial error is improved. Overall, the independent cross validation shows that the 2DVAR method improves the performance of the modeled hourly mean and daily maximum $\mathrm{O}_{3}$ compared to the MFG simulation. This is true not only in the measurement sites, but also elsewhere, with exception of the spatial variation.

In Fig. 5 we compare regionally averaged linear trends in annual percentiles (levels: 0, 2, 5, 10, 25, 50, 75, 90, 95, 98 and 100) of hourly near-surface $\mathrm{O}_{3}$ over the period 1990 2013 for the MFG simulation, the LONGTERM reanalysis, the sum of contributions and the contributions to the trend for different base years. Investigating the additivity of the four contributions (bound, meteo, SE emis and FD emis), we compare the $\mathrm{O}_{3}$ concentration trends in the MFG simulation to the trend in the sum of the contributions (SUM, Fig. 5a). Almost all values fall close to the $1: 1$ line. Only a few of the very weakest $\mathrm{O}_{3}$ trends fall outside the factor 2 lines. Thus, the contribution experiment can be used to explain the MFG $\mathrm{O}_{3}$ trend. Comparing the LONGTERM and MFG trends in near-surface $\mathrm{O}_{3}$ (Fig. $5 \mathrm{~b}$ ), the values are within a factor of 2 for most percentiles and regions. There is a general tendency for the positive MFG trends to be stronger than the reanalyzed trend (LONGTERM). The largest deviations in the $\mathrm{O}_{3}$ trends are in the north, and the relationship between these two is not as linear as in the other two regions. Most of these trends are however not significant. This demonstrates the added value of the measurement model fusion, where errors in the modeled trend are corrected by the analysis. The deviations are small enough to conclude that in most cases the MFG is representative, showing that the MATCH model can be used to understand the trends in the LONGTERM data set. Finally, investigating the impact of the selected base year in the sensitivity simulations, we compare the contributions (bound, emis and meteo) based on 

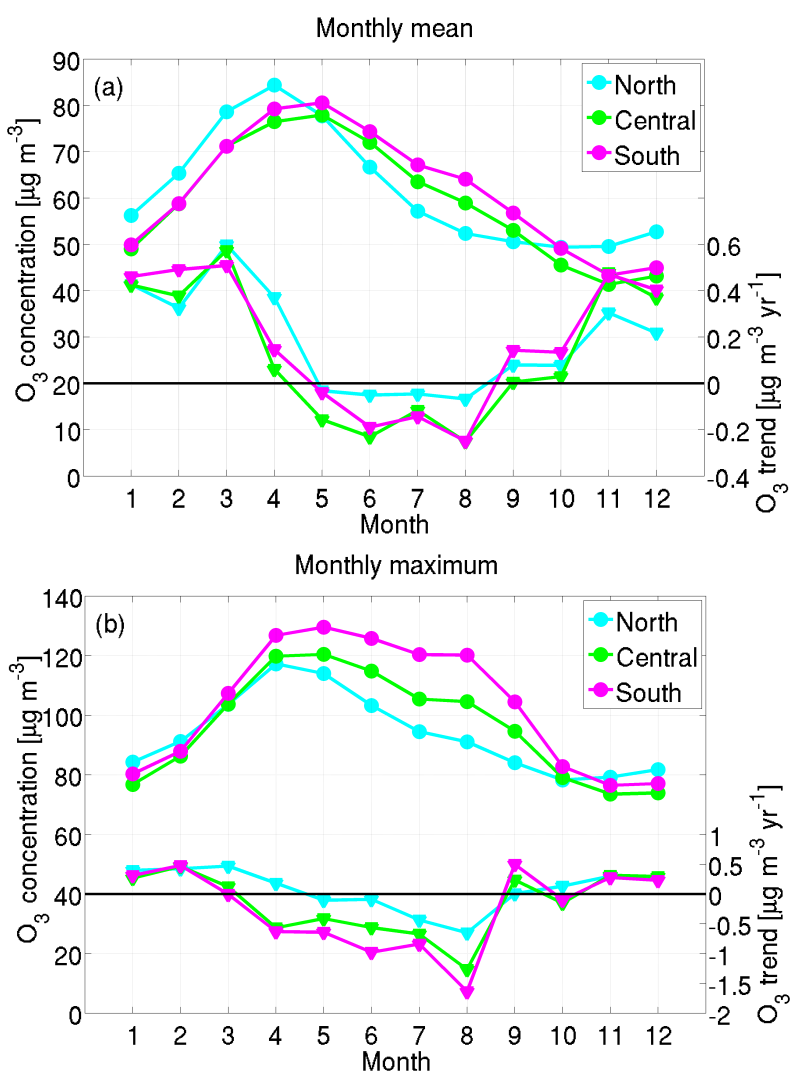

Figure 6. Seasonal cycle of monthly mean (a) and monthly maximum (b) of $1 \mathrm{~h}$ mean near-surface ozone concentrations averaged over the period 1990-2013 (circles; left vertical scale) and region (north, central and south Sweden; see Fig. 3) and the linear trend over the same period of the respective spatially averaged monthly values (triangles; right vertical scale). The different regions are identified by color; see legend. Results from the LONGTERM reanalysis.

keeping the year 2011 constant in the sensitivity simulations to keeping the year 1990 constant (Fig. 5c). Most contributions to the trend in percentiles are robust (Fig. 5c), falling close to the $1: 1$ line. Only a few of the very weakest $\mathrm{O}_{3}$ contribution trends fall outside the factor 2 lines (for the meteo contribution). The contributions to the secular trend in some of the monthly mean and the monthly maximum $1 \mathrm{~h}$ mean near-surface $\mathrm{O}_{3}$ differ more for the two base years than the percentiles (Fig. S5). For monthly mean the trend due to changes in meteorology is stronger for some months (one month is weaker) when 2011 is used as base year compared to 1990 . The other contributions fall within the factor of 2 lines. For monthly maximum the deviation is larger, even differing in sign for the contribution due to variation in meteorology for some months, and a few contributions due to emission change also fall outside the factor of 2 lines.

In conclusion we have shown that the MFG performs well for hourly near-surface $\mathrm{O}_{3}$ concentrations and the 2DVAR analysis improves the performance to almost perfect corre- spondence to the measurements in the measurement locations, and improved performance elsewhere (see the crossvalidation), with the exception of the spatial variation. There is added value of a reanalysis when investigating the trend of near-surface $\mathrm{O}_{3}$ concentrations. The MATCH model can be used to investigate the causes to the reanalyzed $\mathrm{O}_{3}$ trend, but the contribution of meteorology to the monthly maximum is not robust under the choice of base year for all months. In the north the trends in the reanalyzed and the MFG $\mathrm{O}_{3}$ concentrations deviate by more than a factor of 2 for some percentiles. We will focus on this deviation more in the final discussion (Sect. 4).

\subsection{Reanalyzed near-surface ozone in Sweden 1990-2013}

The mean 1990-2013 seasonal variations in monthly mean and monthly maximum of $1 \mathrm{~h}$ mean near-surface $\mathrm{O}_{3}$ are presented in Fig. 6, averaged over the three regions: north, central and south (as defined in Fig. 3). The seasonal variation in the linear trend of the spatially averaged monthly values is also included in the figure. Spatially resolved statistics for annual mean and annual maximum of $1 \mathrm{~h}$ mean near-surface $\mathrm{O}_{3}$ are provided in Fig. 7. The temporal evolution of 11 percentile levels from the 0th (annual minimum $1 \mathrm{~h}$ mean) to the 100th (annual maximum $1 \mathrm{~h}$ mean) are shown in Fig. 8, and the corresponding trends with indication of significance levels are recaptured in the Supplement (Table S2).

\subsubsection{0-2013 period statistics}

The near-surface $\mathrm{O}_{3}$ in Sweden exhibits a seasonal variation, which peaks during spring (Fig. 6). In the north the seasonal maximum concentration occurs in April, whereas it occurs later, in May, in the regions further south. The earlier peak in the north, as compared to the south, was also shown by Klingberg et al. (2009) for in situ observations. In the north, the seasonal peak in monthly mean $\mathrm{O}_{3}$ concentrations is higher than the corresponding seasonal peaks in the other two regions, and this is a feature throughout the whole winter half-year: the monthly mean $\mathrm{O}_{3}$ concentrations are higher in the north than the more southerly regions during October-April. During the summer, the monthly means are higher in the south than in the other two regions. This leads to a 24-year period mean value (Fig. 7) that is highest in the northerly mountains and lowest in central Sweden. This pattern is also supported by Klingberg et al. (2009) based purely on observations, but including a larger number of observation sites through the inclusion of passive diffusion samplers.

For the period mean seasonal variation in monthly maximum $1 \mathrm{~h}$ mean near-surface $\mathrm{O}_{3}$ (Fig. 6b), there is a similar seasonal peak in April-May, but there is also a secondary peak during summer (in August). The monthly maximum $1 \mathrm{~h}$ mean near-surface $\mathrm{O}_{3}$ during March-October becomes higher when looking further south. This applies to both the 

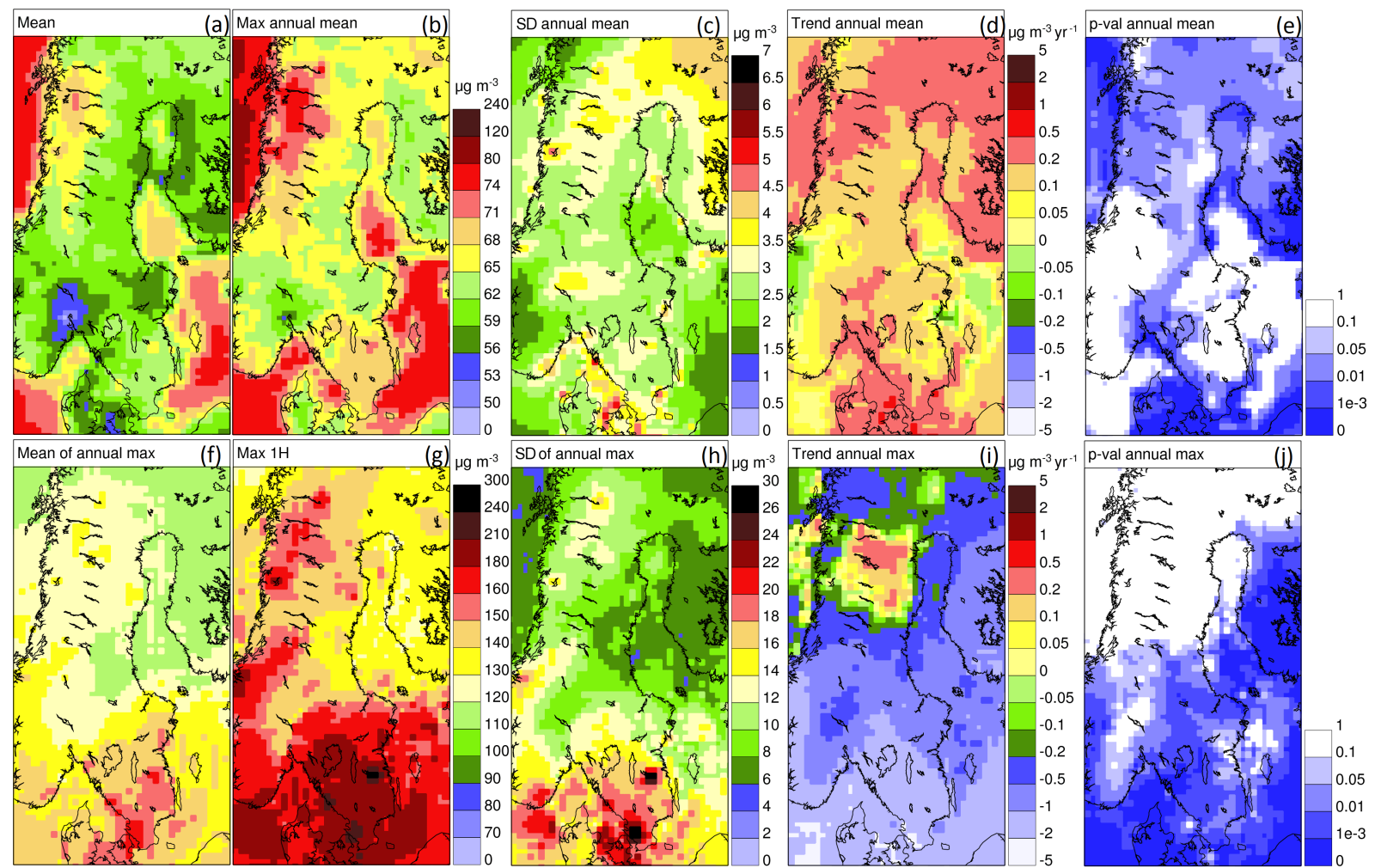

Figure 7. Statistical properties of the annual mean (top row; a-e) and annual maximum $1 \mathrm{~h}$ mean (bottom row; $\mathbf{f}-\mathbf{j}$ near-surface ozone concentration. In the columns from left to right: 1990-2013 mean (a, f), 1990-2013 maximum (b, g), 1990-2013 standard deviation (c, h), linear trend over the period 1990-2013 (d, i) and significance in the linear trend over the period (e, j). Results from the LONGTERM reanalysis.

primary and the secondary seasonal peaks in monthly maximum. The 24-year period mean of the annual maximum of $1 \mathrm{~h}$ mean near-surface $\mathrm{O}_{3}$ (Fig. 7) is lower in central Sweden than in the south and the north, and it is highest in the south.

The lower period mean of the near-surface $\mathrm{O}_{3}$ in the south than in the north is mainly caused by the higher altitude of the latter, mountainous region, whereas the opposite gradient for the annual maximum $1 \mathrm{~h}$ mean is caused by the distance to continental Europe, where the high-ozone events originate from. The difference in spatial patterns between the southern, central and northern parts of Sweden is why we choose the three regions defined in Fig. 3. The period maximum of the annual means and period maximum $1 \mathrm{~h}$ mean near-surface $\mathrm{O}_{3}$ concentrations have similar spatial variation as their respective period means (Fig. 7) The overall 24-year maximum $1 \mathrm{~h}$ mean near-surface $\mathrm{O}_{3}$ reaches above $240 \mathrm{\mu g} \mathrm{m}^{-3}$ in isolated parts of the south, and is generally above $180 \mathrm{\mu g} \mathrm{m}^{-3}$ in the south and $130 \mu \mathrm{g} \mathrm{m}^{-3}$ in the central and northern part of Sweden.

\subsubsection{Trend over the period}

Seasonal variations are also present in the trend of both monthly mean and monthly maximum $1 \mathrm{~h}$ mean near-surface
$\mathrm{O}_{3}$ concentrations (Fig. 6). Monthly means increase strongly during winter and spring (approx. November-April), and decrease moderately (north) or strongly (central and south) during summer (May-August). The trends in monthly maximum $1 \mathrm{~h}$ mean follow a similar pattern. Generally, the rate of change is stronger or at the same level in the central and south as compared to the north. The strongest decrease is in the August maximum $1 \mathrm{~h}$ mean in the south and central, and the strongest increase is in the March monthly mean in the central and north.

The annual mean near-surface $\mathrm{O}_{3}$ (Fig. 7d, e) increases almost everywhere in Sweden over the time period. The trend is however only significant in restricted parts of central and south regions, due to considerable interannual variation in the areas with the highest trend. The annual maximum $1 \mathrm{~h}$ mean near-surface $\mathrm{O}_{3}$ (Fig. 7i, j) significantly decreases in south and central regions, whereas the change in the north is a mixture of increase and decrease, and it is without significance in most areas. 

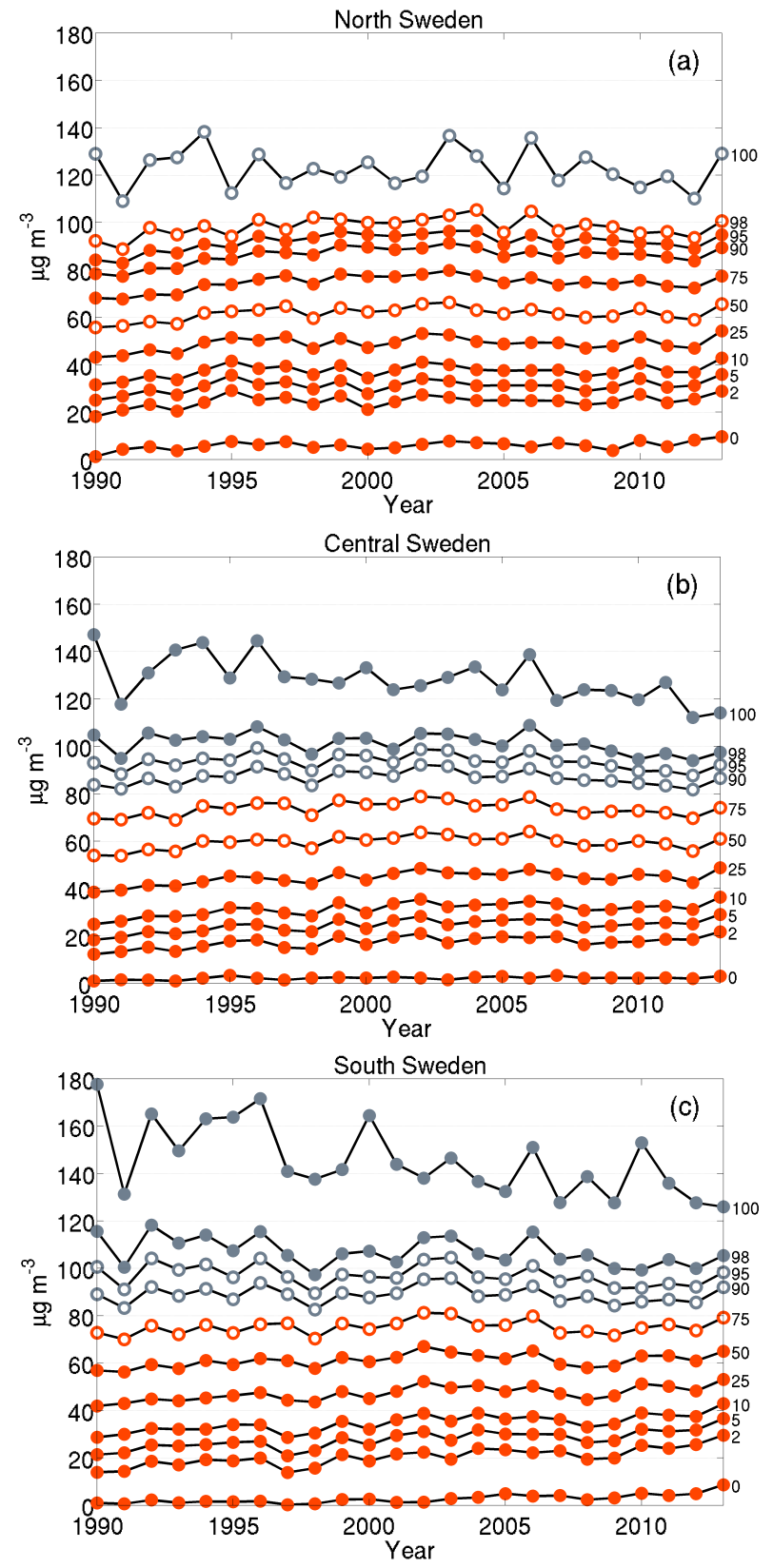

Figure 8. Temporal variation of annual percentiles of near-surface ozone concentrations averaged over the three regions: north (a), central (b) and south (c) of Sweden (see Fig. 3). The line marked 0 is the zero-percentiles (lowest hourly mean near-surface ozone concentration of the year), 100 represents 100th percentile (highest hourly mean near-surface ozone concentration of the year), 50 is the 50th percentile (i.e., annual median of the hourly mean nearsurface ozone concentration). The sign of the corresponding linear trend (see Table S3, including a statistical analysis of the trend) of each percentile is indicated by color: a negative linear trend over 1990-2013 is indicated by grey symbols; a positive trend by orange symbols. Statistically significant trends $(p \leq 0.05)$ are indicated by thick lines. Results from the LONGTERM reanalysis.
We proceed by investigating the trend in annual percentiles (Fig. 8) of hourly near-surface $\mathrm{O}_{3}$ concentration, averaged ${ }^{3}$ over the three Swedish regions (see Fig. 3). In all three regions the low and medium percentiles increase, while the highest percentiles decrease from 1990 until 2013. This was also shown by Simpson et al. (2014) based on observations for northern Europe and based on observations for Europe, US and East Asia by Lefohn et al. (2017). Further, using hourly $\mathrm{O}_{3}$ observations, Karlsson et al. (2017) showed that reduced concentrations in northern Europe were restricted to the highest $\mathrm{O}_{3}$ concentrations during summer daytime, while the increase in low and mid-range concentrations occurred during wintertime at both day and night.

In central and south regions the decrease in the highest near-surface $\mathrm{O}_{3}$ percentiles are significant and stronger than in the north, and this decrease is evident throughout the maximum $10 \%$ percentile range (although the change is not significant for the 90th and 95th percentile levels; see Fig. 3). This change is mainly caused by decreased high values during the summertime. In the north, only the annual maximum $1 \mathrm{~h}$ mean decreases and the interannual variability is stronger than the rate of change, indicated by the lack of significance for this percentile. The medium and low percentile increase in the north is moderate, but significant, for most percentiles up to the 95th, with very similar rates of change. In the central and south the change in the low percentiles is highly significant and stronger than in the north. This is an indication that the increase in low near-surface $\mathrm{O}_{3}$ concentrations cannot only be explained by increasing background. As a result of the decrease in high and increase in low percentiles, there was a narrowing of the range of the near-surface $\mathrm{O}_{3}$ concentrations over the period. This was also observed in the UK by Jenkin (2008) for 1990 until the early 2000s and in the US by Simon et al. (2015) for 1998-2013, both studying urban and regional background measurements across the respective countries. Jenkin (2008) interpreted it as caused by three major influences: (i) increasing hemispheric background, (ii) decreasing severity in high-ozone events arising from the European continent and (iii) decreasing local-scale removal of ozone due the control of $\mathrm{NO}_{x}$ emissions. Simon et al. (2015) interpreted the US evolution as a response to the substantial decrease in $\mathrm{O}_{3}$ precursor emissions in the US over the time period. Decreased primary NO emissions results in decreased $\mathrm{O}_{3}$ titration close to combustion sources, but also reduces local $\mathrm{O}_{3}$ further away from the emissions sources when there is little photolysis (especially in the winter and during nighttime). In the next section we investigate the impact of Swedish and European emission decrease over the period, and relate this to the impact of change in the chemical composition of the hemispheric background and meteorological variations.

\footnotetext{
${ }^{3}$ The percentile is calculated per grid square for all hours in each year, then regional mean annual percentiles are calculated and finally the trend is calculated based on these averaged percentiles.
} 

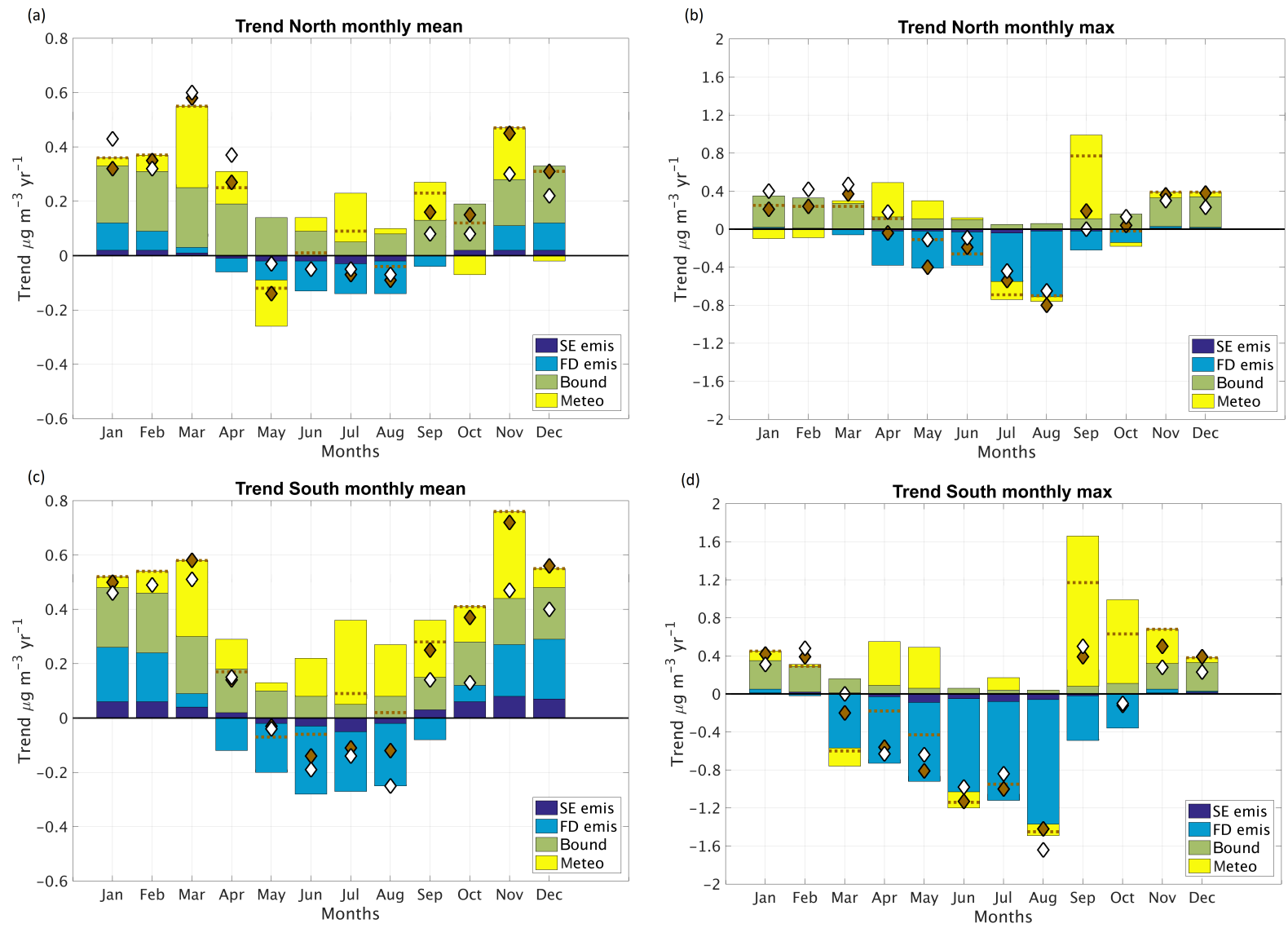

Figure 9. Linear trend over 1990-2013 in monthly mean (a, c) and monthly maximum $1 \mathrm{~h}$ mean (b, d) near-surface ozone concentration for the north (a, b) and the south (c, d) Sweden regions (see Fig. 3). Reanalyzed (white diamond; LONGTERM reanalysis) and modeled first guess (MFG) near-surface ozone trend (brown diamond), and modeled contributions to the near-surface ozone trend due to change in emissions: anthropogenic Swedish (dark blue, SE emis) and full domain, non-Swedish (light blue, FD emis) emissions; trend in top and lateral boundaries of relevant species (dark yellow, bound) and variation in meteorology (light yellow, meteo). The sum of the modeled contributions is indicated by the dashed brown line.

\subsection{Attribution of the change in near-surface ozone}

In this section we quantify the contributions of physical factors to the modeled trend of near-surface $\mathrm{O}_{3}$ concentrations in Sweden during the period 1990-2013. We investigate the impact of the trend in lateral and upper boundaries, meteorological variations and Swedish and European (i.e., full domain, non-Swedish) anthropogenic emission change. In Figs. 9 and 10 the contributions to the trend in seasonal variations and percentiles are delineated for the north and south regions.

We start our attribution by analyzing the impact of changing hemispheric background levels of relevant chemical species ("bound" bars in Figs. 9 and 10). These contribute to an increase in monthly mean and maximum $1 \mathrm{~h}$ mean throughout the year and for all percentiles, mainly as a result of our assumption of an increasing $\mathrm{O}_{3}$ concentration trend in the lateral and upper boundaries during the 1990s and constant boundary conditions for $\mathrm{O}_{3}$ during the rest of the period. There is a seasonal variation in the trend of the boundary contribution, with lower impact during summer. This variation is likely a result of an $\mathrm{O}_{3}$ destruction process that is stronger during summer than winter, such as dry deposition to vegetation and photolysis of ozone. The seasonal variation in the contribution to the trend from the boundary impacts both monthly mean and maximum $1 \mathrm{~h}$ mean. Our representation of the trend in the concentration of species at the model domain boundary is climatological. The climatological upper boundary means that the interannual variations in near-surface $\mathrm{O}_{3}$ are likely underestimated in remote locations. The impact on interannual variations may be largest at high altitudes or far away from the major anthropogenic sources. Hess and Zbinden (2013) showed the importance of the stratospheric contribution to the interannual variation at Mace Head and Jungfraujoch; it is possibly also important in the north of Sweden, especially in the mountainous areas. Such variation is not captured by the boundary settings, but it is indirectly included in the reanalyses data sets through the 
(a)

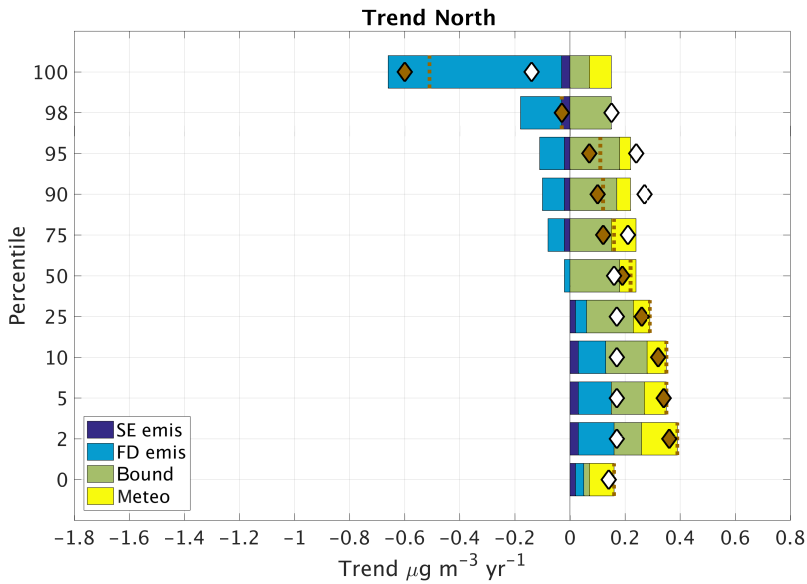

(b)

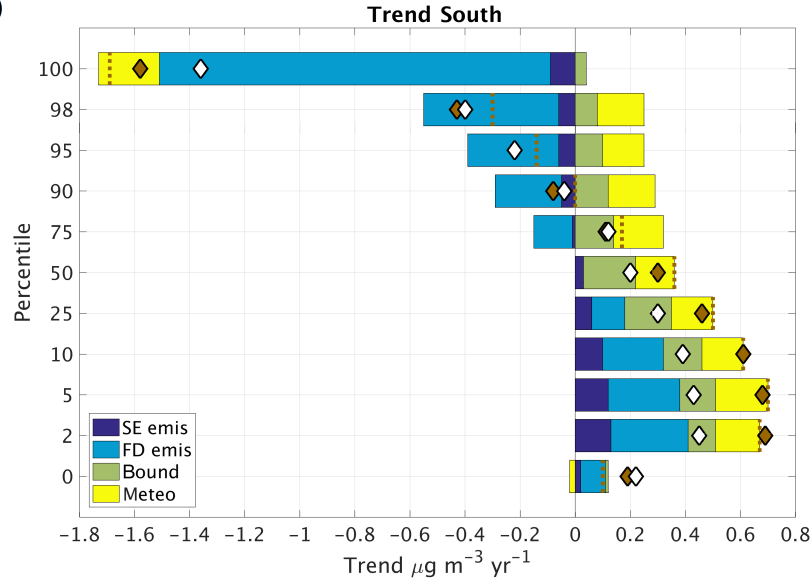

Figure 10. Linear trends over 1990-2013 in annual percentiles of hourly mean near-surface ozone concentrations for the north (a) and the south (b) Sweden regions. Reanalyzed (white diamond; LONGTERM reanalysis) and modeled MFG near-surface ozone trend (brown diamond) and modeled contributions to the nearsurface ozone concentration trend due to change in emissions: anthropogenic Swedish (dark blue, SE emis) and full domain, nonSwedish (light blue, FD emis) emissions; trend in top and lateral boundaries of relevant species (dark yellow, bound) and variation in meteorology (light yellow, meteo). The sum of the modeled contributions is indicated by the dashed brown line.

variation in the measurements included in the variational data analysis. As a consequence, the MFG and "bound" simulations underestimate the interannual variability as compared to observations and the reanalysis (see Table 2), and this could also affect the "bound" trend.

The impact of meteorological low-frequency variations ("meteo") during the 24 years is also an important factor, but more difficult to interpret. The meteorological variation causes a positive trend in near-surface $\mathrm{O}_{3}$ concentrations for most monthly means and maxima, as well as for most percentiles. Note the shift from a generally strong positive contribution to a strong negative contribution from the 98th percentile to the 100th percentile in the south. The meteorolog-
Table 3. Linear trend during 1990-2013 of policy-related metrics in the three Swedish regions north, central and south (see Fig. 3). Asterisks $\left(*, * *\right.$, and $\left.{ }^{* * *}\right)$ indicate that the trend is significant $(p \leq$ $0.05, p \leq 0.01, p \leq 0.001$, respectively).

\begin{tabular}{|c|c|c|c|}
\hline Metrics & North & Central & South \\
\hline Mean $\left(\mu \mathrm{g} \mathrm{m}^{-3} \mathrm{yr}^{-1}\right)$ & $+0.18^{*}$ & +0.13 & $+0.18 *$ \\
\hline SOMO35 (ppb(v) d yr $\left.{ }^{-1}\right)$ & +14 & -3.1 & -4.7 \\
\hline Maximum $8 \mathrm{~h}$ mean $\left(\mu \mathrm{g} \mathrm{m}^{-3} \mathrm{yr}^{-1}\right)$ & -0.11 & $-0.68^{* *}$ & $-1.2^{* *}$ \\
\hline Maximum $1 \mathrm{~h}$ mean $\left(\mu \mathrm{g} \mathrm{m}^{-3} \mathrm{yr}^{-1}\right)$ & -0.14 & $-0.82^{* *}$ & $-1.4^{* * *}$ \\
\hline AOT40c $\left(\mathrm{ppm}(\mathrm{v}) \mathrm{h} \mathrm{yr}^{-1}\right)$ & -0.01 & $-0.07^{*}$ & -0.09 \\
\hline AOT40f (ppm(v) h yr $\left.{ }^{-1}\right)$ & +0.03 & -0.09 & $-0.12 *$ \\
\hline \#hours $>80 \mu \mathrm{g} \mathrm{m}^{-3}\left(\# \mathrm{yr}^{-1}\right)$ & $+26^{*}$ & +1.7 & +6.6 \\
\hline$\#$ days $>70 \mu \mathrm{g} \mathrm{m}^{-3}\left(\# \mathrm{yr}^{-1}\right)$ & +1.3 & +0.73 & +1.1 \\
\hline$\#$ days $>120 \mu \mathrm{g} \mathrm{m}^{-3}\left(\# \mathrm{yr}^{-1}\right)$ & +0.01 & $-0.12^{*}$ & $-0.32^{* *}$ \\
\hline
\end{tabular}

ical influence on the trend is as large as the impact of the change in boundary for most percentile levels in the south, while it is weaker for most percentile levels in the north.

During the period 1990-2013 both European (full domain, non-Swedish) and Swedish emissions decreased strongly. There is a strong seasonality in the impact of the decreasing European emissions, and the contribution to the trend of the Swedish emissions follows the same pattern but with smaller magnitude (see Fig. 9, "FD emis" and "SE emis", respectively). During summer the decreasing emissions acted to lower both the monthly mean and maximum $1 \mathrm{~h}$ mean. During winter the trend in monthly maximum $1 \mathrm{~h}$ mean is unaffected by the change in emissions, indicating that the highest near-surface $\mathrm{O}_{3}$ concentrations during winter are due to sources other than local $\mathrm{O}_{3}$ production. Emission decreases caused increases in monthly mean near-surface $\mathrm{O}_{3}$ concentrations in the winter, due to reduced $\mathrm{O}_{3}$ destruction by primary NO emission. Trends in percentiles (Fig. 10) show that the emission decrease caused decreases to percentiles higher than the 50th level, and increases below. The impact is stronger in the south than in the north, which is expected due to the south being closer to the European continent. The contribution of the trend in emissions is often stronger than the changing boundary, e.g., in the south for most percentiles and for monthly maximum $1 \mathrm{~h}$ mean during the summer halfyear in both regions. Thus, the observed increase in low and medium near-surface $\mathrm{O}_{3}$ levels is caused by a mixture of both changes to the hemispheric background levels and emission reductions of $\mathrm{O}_{3}$ precursors, while the decrease in the high percentile levels is mainly caused by emission decrease.

\subsection{Implications for health and vegetation impacts}

For the protection of vegetation, the target value by EU (EU directive 2008/50/EC) states that the 5-year mean AOT40 (near-surface $\mathrm{O}_{3}$ concentrations above $40 \mathrm{ppb}(\mathrm{v})$ accumulated over May-July; AOT40c) must not exceed $9 \mathrm{ppm}(\mathrm{v}) \mathrm{h}$, and as a long-term goal AOT40c must not exceed $3 \mathrm{ppm}(\mathrm{v}) \mathrm{h}$ during a calendar year. For protection of human health the 
target value by EU (EU directive 2008/50/EC) states that the daily maximum running $8 \mathrm{~h}$ mean near-surface $\mathrm{O}_{3}$ concentrations must not exceed $120 \mu \mathrm{g} \mathrm{m}^{-3}$ for more than 25 days per year as a 3-year mean, and as a long-term goal the daily maximum of $8 \mathrm{~h}$ mean near-surface $\mathrm{O}_{3}$ concentrations must not exceed $120 \mathrm{\mu g} \mathrm{m}^{-3}$ at all. Sweden has formulated $16 \mathrm{en-}$ vironmental quality objectives, including clean air, alongside specifications to help reach these objectives. The following specifications are currently valid for near-surface $\mathrm{O}_{3}$ concentrations in Sweden (NV, 2015): the hourly mean must not exceed $80 \mu \mathrm{g} \mathrm{m}^{-3}$, the daily maximum $8 \mathrm{~h}$ mean must not exceed $70 \mu \mathrm{g} \mathrm{m}^{-3}$ and AOT40f $\left(\mathrm{O}_{3}\right.$ concentrations above $40 \mathrm{ppb}(\mathrm{v})$ accumulated over April-September) must not exceed 5 ppm(v) h. SOMO35 (the sum of ozone means ${ }^{4}$ over $35 \mathrm{ppb}(\mathrm{v}))$ is used as a metric describing human exposure. The cut-off value of $35 \mathrm{ppb}(\mathrm{v})$ is often used in risk assessments as a statistically significant increase in mortality has been observed at daily ozone concentrations $>25-35 \mathrm{ppb}(\mathrm{v})$ (Bell et al., 2006; Amann et al., 2008; Orru et al., 2013). In Table 3 we present the linear trends in our reanalysis data set for these metrics, and have collected geographically resolved statistics, such as the period mean, maximum and linear trend in the Supplement (Figs. S6-S10).

The narrowing of the $\mathrm{O}_{3}$ concentration range, especially through increasing lower percentiles, can impact human and vegetation exposure to $\mathrm{O}_{3}$. The effect metrics based on accumulation of values above a threshold (AOT40c; AOT40f; SOMO35) and the number of days with daily maximum of $8 \mathrm{~h}$ mean near-surface $\mathrm{O}_{3}$ concentrations exceeding $120 \mu \mathrm{g} \mathrm{m}^{-3}$ have decreased over the period in the south and central regions, as they have the highest values in the year. This is in agreement with the decrease in the highest percentiles in these regions (see Table S2). Conversely, the metrics with lower threshold values increase, such as the number of hours exceeding $80 \mu \mathrm{g} \mathrm{m}^{-3}$ and the number of days with daily maximum $8 \mathrm{~h}$ mean near-surface $\mathrm{O}_{3}$ concentrations exceeding $70 \mu \mathrm{g} \mathrm{m}^{-3}$. This increase is significant in the north, whilst it is not significant in the south and central. This agrees with the change in medium and low percentiles. A continued increase in low values would cause a continued increase in these metrics, and would eventually reverse the decreasing trend to an increase. This is valid specifically for those metrics with accumulation of values or higher thresholds, such as SOMO35 and AOT40c.

\section{Discussion}

This work improves upon previous studies by investigating the trends in near-surface $\mathrm{O}_{3}$ concentrations via a combination of both observed and modeled data The respective advantages of modeling (geographical and temporal coverage)

\footnotetext{
${ }^{4}$ For SOMO35 the mean is defined as the daily maximum of running $8 \mathrm{~h}$ mean near-surface $\mathrm{O}_{3}$ concentrations and the accumulation is over a year unless otherwise is stated.
}

and observations (the most reliable $\mathrm{O}_{3}$ concentration estimate at a discreet point) can be exploited through variational data analysis to reach a greater understanding of the atmospheric state, and the model can further be used as a tool to explain what is described.

Our results should, however, also be viewed in the context of their limitations. The length scale of the variational data analysis is set to $1000 \mathrm{~km}$, implying a large horizontal influence of the observation increments. This is related to the sparse network of regional background observations but also to the relatively small emissions of $\mathrm{O}_{3}$ precursors in Sweden resulting in weak horizontal gradients of near-surface $\mathrm{O}_{3}$ on the regional background scale. The large length scale is also a filtering of local influences in the observations, consequently suppressing sharp gradients in the analysis. However, the horizontal variation in near-surface ozone is larger in the south than in the north, and the large length scale chosen in the data analysis may cause too-weak horizontal gradients in the reanalysis data set, especially in the south. An improvement to this would be to describe the geographical variation of near-surface ozone in the background error field, rather than representing this with a constant value as done in this study. The model simulations have a relatively coarse horizontal resolution, meaning that processes that are more local in origin are not captured by the model - these include the role of local topography or coastal climate for the nighttime boundary layer stability (Klingberg et al., 2011), or local emission sources. As a result, the variational data analysis scheme will spread such features to parts of the model results where they are not valid. Some of the southerly sites in the variational data analysis are known to experience nighttime inversions with associated depletion of near-surface $\mathrm{O}_{3}$ and the reanalysis will thus be affected by this. Introducing a geographically varying length scale and background error in the variational data analysis and an improvement in the spatial resolution of the model would improve the spatial representation of the analysis, the latter since the difference between observation and model has the potential to decrease at these observation sites.

As with all modeling studies, the model cannot perform better than the quality of the forcing input data. Knowledge of emissions in the beginning of the 24-year period is less comprehensive than at the end, which could introduce artificial trends to the MFG. The trends in lateral and top boundary conditions are taken from the work by Engardt et al. (2017) and are based on observed trends at regional background location in Europe. The upper boundaries are especially poorly constrained in our study, and as a consequence so is the stratospheric contribution to the interannual variation and trend. The variational data analysis reduces the impact at the surface caused by errors in the lateral and upper model boundaries. However, the reanalysis may still be affected in regions with sparse measurement coverage. This can affect the attribution to the trend. In this study the MFG simulation captures the observed (reanalyzed) trend reason- 
ably well, but there is a discrepancy between the reanalysis and MFG trend for most percentile levels in north Sweden. To investigate this in more detail, we have compared the error in trend by percentile (the difference between the trends in MFG and LONGTERM) to the trend caused by the four contributions (bound, meteo, SE emis and FD emis). The resulting figure is included in the Supplement (Fig. S11). There is a $1: 1$ relation between the impact of the trend in the European emissions and the deviation between the MFG and the LONGTERM trends. This could be caused by overestimation of the European emissions trend. A similar tendency is seen for the Swedish emission contribution in the central and south regions. This calls for emission inventories to be improved in order to assure the trend in ozone precursor emissions is correct. Another reason for this could be the toostrong model sensitivity to the European emission trend in the north. If this was true, it would have implications for sensitivity studies that consider the future development of nearsurface $\mathrm{O}_{3}$. In studies relating the impacts of future climate change to future anthropogenic precursor emission change, a robust conclusion for most models is that the impact on annual or summertime mean near-surface $\mathrm{O}_{3}$ concentrations of future precursor emissions is much stronger than the impact of climate change (e.g., Engardt et al., 2009; Langner et al., 2012b; Watson et al., 2016). If models are too sensitive to trends in emissions in remote areas, compared to other processes, such a conclusion might change. Parrish et al. (2014) also compared observed and modeled trends and found that the three chemistry-climate models studied failed to reproduce the observed trends - the modeled $\mathrm{O}_{3}$ concentration trend was approximately parallel to the estimated trend in anthropogenic precursor emissions of $\mathrm{NO}_{x}$, whilst observed $\mathrm{O}_{3}$ concentration changes increased more rapidly than these emission estimates. This implies that there is a lack of knowledge relating to controls of concentrations of tropospheric $\mathrm{O}_{3}$. The question of whether it is the trend in ozone precursor emissions or the model sensitivity to emissions which needs improving is left for future studies.

Our study shows that the impact of meteorological variability on the trend changes strongly from lower percentile levels to the very highest (in the south), with a shift from a positive to a negative contribution (see Fig. 10). Thus, conclusions drawn on the importance of meteorological variability in comparison to other factors such as changes in emissions will vary strongly depending on the metric that is studied. We have also studied the impact of base year in the sensitivity study (1990 vs. 2011; see Figs. 5c and S5). The attribution to the trend is robust for all percentiles, including the annual maximum, whereas the monthly maximum is not robust for emissions and meteorological variation. So far studies of the future development of near-surface $\mathrm{O}_{3}$ have focused on long-term means such as summer mean (e.g., Langner et al., 2012a, b; Watson et al., 2016), whereas the direction of cause of high-frequency metrics, such as the higher percentiles we show here, have not been established and should be investigated further.

Finally, we conducted a trend analysis of the reanalyzed near-surface $\mathrm{O}_{3}$ using linear regression. We have chosen to present the trend in the LONGTERM data set in all analyzes, regardless of whether it is statistically significant or not. We stress that a trend contains valid information even where it is not statistically significant - and it will become significant if the change and variability remains the same over time. We also recognize that there are other methods of investigating the statistical behavior of the data set, and therefore welcome further use of the data, which may be provided upon request to the corresponding author.

\section{Conclusions}

- We constructed two hourly reanalyses of near-surface $\mathrm{O}_{3}$ for Sweden for the period 1990-2013: one timeconsistent reanalysis and one using all available hourly measurements. Both data sets are available upon request from the corresponding author.

- We evaluated the performance of the reanalyzed nearsurface $\mathrm{O}_{3}$ and mainly found improved performance compared to the MATCH model.

- Our results show the following:

- High near-surface $\mathrm{O}_{3}$ concentrations in Sweden are decreasing and low $\mathrm{O}_{3}$ concentrations are increasing.

- Health and vegetation impacts due to high nearsurface $\mathrm{O}_{3}$ concentrations (quantified by policyrelated threshold metrics) have decreased in central and south Sweden as a result of the decrease in the highest ozone values.

- Decreasing emissions in Europe have led to decreasing summertime near-surface $\mathrm{O}_{3}$ concentrations, as well as a decrease in the highest concentrations.

- The rising low concentrations of near-surface $\mathrm{O}_{3}$ in Sweden are caused by a combination of rising hemispheric background $\mathrm{O}_{3}$ concentrations, meteorological variations and $\mathrm{O}_{3}$ response to European $\mathrm{O}_{3}$ precursor emission regulation.

- There is a discrepancy between modeled and observed (reanalyzed) $\mathrm{O}_{3}$ trends in northern Sweden. This could be caused by erroneous trends in the historical anthropogenic ozone precursor emissions used here or that our model is too sensitive to changes in emissions. If the latter is true, it implies that the evolution of future precursor emissions may have a weaker impact on future nearsurface $\mathrm{O}_{3}$ concentrations than shown in earlier 
studies (e.g., Langner et al., 2012a, b; Watson et al., 2016).

- The results show that the impact of meteorological variability changes strongly from lower percentiles levels to the very highest in the south. In studies of future development, maximum ozone, and what causes it to change, should be investigated further.

Data availability. The data sets is available upon request from the authors.

\section{The Supplement related to this article is available online at https://doi.org/10.5194/acp-17-13869-2017- supplement.}

Competing interests. The authors declare that they have no conflict of interest.

Acknowledgements. This project was funded by the Swedish Environmental Protection Agency (EPA), through funding directly to the reanalysis (contract no. 2251-14-016) and through the research program Swedish Clean Air and Climate (SCAC) and NordForsk through the research program Nordic WelfAir (grant no. 75007). The annual mapping with the MATCH Sweden system is funded by the Swedish EPA.

Thanks to Sverre Solberg (NILU, Norway) for all of the help, especially with the selection of Norwegian observation sites.

Edited by: Maria Kanakidou

Reviewed by: two anonymous referees

\section{References}

Akimoto, H.: Global air quality and pollution, Science, 302, 17161719, https://doi.org/10.1126/science.1092666, 2003.

Alpfjord, H. and Andersson, C.: Nationell miljöövervakning med MATCH Sverige-systemet - ny metodik, utvärdering och resultat för åren 2012-2013, Swedish Meteorological and Hydrological Institute, Norrköping, Sweden, SMHI report no. 2015-7, 45 pp., available at: http://www.smhi.se/klimatdata/miljo/atmosfarskemi (last access: 3 March 2017), 2015 (in Swedish).

Amann, M., Derwent, D., Forsberg, B., Hänninen, O., Hurley, F., Krzyzanowski, M., de Leeuw, F., Liu, S. J., Mandin, C., Schneider, J., Schwarze, P., and Simpson, D.: Health risks of ozone from long-range transboundary air pollution, Copenhagen, World Health Organization, Regional office for Europe, 2008.

Andersson, C., Langner, J., and Bergström, R.: Interannual variation and trends in air pollution over Europe due to climate variability during 1958 isn't in document 2001 simulated with a regional CTM coupled to the ERA40 reanalysis, Tellus B, 59, 7798, https://doi.org/10.1111/j.1600-0889.2006.00196.x, 2007.
Andersson, C. and Engardt, M.: European ozone in a future climate - the importance of changes in dry deposition and isoprene emissions, J. Geophys. Res., 115, D02303, https://doi.org/10.1029/2008JD011690, 2010.

Andersson, C., Bergström, R., Bennet, C., Robertson, L., Thomas, M., Korhonen, H., Lehtinen, K. E. J., and Kokkola, H.: MATCHSALSA - Multi-scale Atmospheric Transport and CHemistry model coupled to the SALSA aerosol microphysics model Part 1: Model description and evaluation, Geosci. Model Dev., 8, 171-189, https://doi.org/10.5194/gmd-8-171-2015, 2015.

Bell, M. L., Peng, R. D., and Dominici, F.: The exposure-response curve for ozone and risk of mortality and the adequacy of current ozone regulations, Environ. Health Perspect., 114, 532-536, 2006.

Carter, W. P.: Condensed atmospheric photooxidation mechanisms for isoprene, Atmos. Environ., 30, 4275-4290, 1996.

Cooper, O. R., Parrish, D. D., Ziemke, J., Cupeiro, M., Galbally, I. E., Gilge, S., Horowitz, L., Jensen, N. R., Lamarque, J.-F., Naik, V., Oltmans, S. J., Schwab, J., Shindell, D. T., Thompson, A. M., Thouret, V., Wang, Y., and Zbinden, R. M.: Global distribution and trends of tropospheric ozone: an observation-based review, Elementa, 2, 1-28, https://doi.org/10.12952/journal.elementa.000029, 2014.

Courtier, P., Thépaut, J.-N., and Hollingsworth, A.: A strategy for operational implementation of 4D-Var, using an incremental approach, Q. J. Roy. Meteor. Soc., 120, 1367-1388, 1994.

Dahlgren, P., Landelius, T., Kållberg, P., and Gollvik, S.: A high-resolution regional reanalysis for Europe, Part 1: Threedimensional reanalysis with the regional HIgh-Resolution Limited-Area Model (HIRLAM), Q. J. Roy. Meteor. Soc., 142, 2119-2131, https://doi.org/10.1002/qj.2807, 2016.

Dee, D. P., Uppala, S., Simmons, A., Berrisford, P., Poli, P., Kobayashi, S., Andrae, U., Balmaseda, A., Balsamo, G., Bauer, P., Bechtold, P., Beljaars, A. C. M., van de Berg, L., Bidlot, J.R., Bormann, N., Delsol, C., Dragani, R., Fuentes, M., Geer, A., Haimberger, L., Healy, S., Hersbach, H., Hólm, E. V., Isaksen, L., Kållberg, P. W., Köhler, M., Matricardi, M., McNally, A., Monge-Sanz, B. M., Morcrette, J.-J., Park, B.-K., Peubey, C., De Rosnay, P., Tavolato, C., Thepaut, J.-J., and Vitart, F.: The ERA-Interim reanalysis: configuration and performance of the data assimilation system, Q. J. Roy. Meteor. Soc., 137, 553-597, 2011.

Denby, B. and Spangl, W.: The combined use of models and monitoring for applications related to the European air quality directive: a working sub-group of FAIRMODE, Proceedings of the HARMO13 conference, Paris, France, June 2010, H13261, available at: http://fairmode.jrc.ec.europa.eu/document/ fairmode/event/presentation/20100601-h13-261.pdf (last access: 3 March 2017), 2010.

Derwent, R. G., Manning, A. J., Simmonds, P. G., and Spain, T. G.: Analysis and interpretation of 25 years of ozone observations at the Mace Head Atmospheric Research Station on the Atlantic Ocean coast of Ireland from 1987 to 2012, Atmos. Environ., 80, 361-368, 2013.

Derwent, R. G., Utembe, S. R., Jenkin, M. E., and Shallcross, D. E.: Tropospheric ozone production regions and the intercontinental origins of surface ozone over Europe, Atmos. Environ., 112, 216-224, 2015. 
Engardt, M., Bergström, R., and Andersson, C.: Climate and emissions changes contributing to changes in near-surface ozone in Europe over the coming decades - Results from model studies, Ambio, 38, 452-458, 2009.

Engardt, M., Simpson, D., Schwikowski, M., and Granat, L.: Deposition of sulphur and nitrogen in Europe 1900-2050. Model calculations and comparison to historical observations, Tellus B, 69, 1328945, https://doi.org/10.1080/16000889.2017.1328945, 2017.

EU directive 2008/50/EC: directive 2008/50/EC of the European parliament and of the council of 21 May 2008 on ambient air quality and cleaner air for Europe, Official Journal of the European Union, 44 pp., available at: http://data.europa.eu/eli/dir/ 2008/50/oj (last access: 16 November 2017), 2008.

Finlayson-Pitts, B. J. and Pitts, J. N.: Chemistry of the upper and lower atmosphere. Theory, experiments and applications, Academic press, California, USA, 969 pp., ISBN: 0-12-257060, 2000.

Fiore, A. M., Dentener, F. J., Wild, O., Cuvelier, C., Schultz, M. G., Hess, P., Textor, C., Schulz, M., Doherty, R. M., Horowitz, L. W., MacKenzie, I. A., Sanderson, M. G., Shindell, D. T., Stevenson, D. S., Szopa, S., Van Dingenen, R., Zeng, G., Atherton, C., Bergmann, D., Bey, I., Carmichael, G., Collins, W. J., Duncan, B. N., Faluvegi, G., Folberth, G., Gauss, M., Gong, S., Hauglustaine, D., Holloway, T., Isaksen, I. S. A. Jacob, D. J., Jonson, J. E., Kaminski, J. W., Keating, T.J., Lupu, A., Marmer, E., Montanaro, V., Park, R. J., Pitari, G., Pringle, K. J., Pyle, J. A., Schroeder, S., Vivanco, M. G., Wind, P., Wojcik, G., Wu, S., and Zuber, A.: Multimodel estimates of intercontinental source-receptor relationships for ozone pollution, J. Geophys. Res., 114, D04301, https://doi.org/10.1029/2008JD010816, 2009.

Fiore, A. M., Levy II, H., and Jaffe, D. A.: North American isoprene influence on intercontinental ozone pollution, Atmos. Chem. Phys., 11, 1697-1710, https://doi.org/10.5194/acp-111697-2011, 2011.

Fusco, A. C. and Logan, J. A.: Analysis of 1970-1995 trends in tropospheric ozone at Northern Hemisphere midlatitudes with the GEOS-CHEM model, J. Geophys. Res., 108, D154449, https://doi.org/10.1029/2002JD002742, 2003.

Gaudel, A., Ancellet, G., and Godin-Beekmann, S.: Analysis of 20 years of tropospheric ozone vertical profiles by lidar and ECC at Observatoire de Haute Provence (OHP) at $44^{\circ} \mathrm{N}, 6.7^{\circ} \mathrm{E}$, Atmos. Environ., 113, 78-89, https://doi.org/10.1016/j.atmosenv.2015.04.028, 2015.

Granier, C., Bessagnet, B., Bond, T., D’Angiola, A., Denier van der Gon, H., Frost, G. J., Heil, A., Kaiser, J. W., Kinne, S., Klimont, Z., Kloster, S., Lamarque, J.-F., Liousse, C., Masui, T., Meleux, F., Mieville, A., Ohara, T., Raut, J.-C., Riahi, K., Schultz, M. G., Smith, S. J., Thompson, A., van Aardenne, J., van der Werf, G. R., and van Vuuren D. P.: Evolution of anthropogenic and biomass burning emissions of air pollutants at global and regional scales during the 1980-2010 period, Climatic Change, 109, 163-190, https://doi.org/10.1007/s10584011-0154-1, 2011.

Hess, P. G. and Zbinden, R.: Stratospheric impact on tropospheric ozone variability and trends: 1990-2009, Atmos. Chem. Phys., 13, 649-674, https://doi.org/10.5194/acp-13-649-2013, 2013.
Hjellbrekke, A.-G. and Solberg, S.: Ozone measurements 2013, EMEP/CCC-report 2/2015, Norwegian institute for Air Research (NILU), Kjeller, Norway, 2015.

Inness, A., Baier, F., Benedetti, A., Bouarar, I., Chabrillat, S., Clark, H., Clerbaux, C., Coheur, P., Engelen, R. J., Errera, Q., Flemming, J., George, M., Granier, C., Hadji-Lazaro, J., Huijnen, V., Hurtmans, D., Jones, L., Kaiser, J. W., Kapsomenakis, J., Lefever, K., Leitão, J., Razinger, M., Richter, A., Schultz, M. G., Simmons, A. J., Suttie, M., Stein, O., Thépaut, J.-N., Thouret, V., Vrekoussis, M., Zerefos, C., and the MACC team: The MACC reanalysis: an $8 \mathrm{yr}$ data set of atmospheric composition, Atmos. Chem. Phys., 13, 4073-4109, https://doi.org/10.5194/acp13-4073-2013, 2013.

Jacob, D. J., Logan, J. A., Yevich, R. M., Gardner, G. M., Spivakovsky, C. M., Wofsy, S. C., Munger, J. W., Sillman, S., Prather, M. J., Rodgers, M. O., Westberg, H., and Zimmerman, P. R.: Simulation of summertime ozone over North-America, J. Geophys. Res., 98, 14797-14816, https://doi.org/10.1029/93JD01223, 1993.

Jenkin, M. E.: Trends in ozone concentration distributions in the UK since 1990: local, regional and global influences, Atmos. Environ., 42, 5434-5445, 2008.

Jonson, J. E., Simpson, D., Fagerli, H., and Solberg, S.: Can we explain the trends in European ozone levels?, Atmos. Chem. Phys., 6, 51-66, https://doi.org/10.5194/acp-6-51-2006, 2006.

Kalnay, E.: Atmospheric modeling, data assimilation and predictability, Cambridge University Press, Cambridge and New York, USA, ISBN 0-521-79629-6, 2003.

Karlsson, P. E., Klingberg, J., Engardt, M., Andersson, C., Langner, J., Pihl Karlsson, G., and Pleijel, H.: Past, present and future concentrations of ground-level ozone and potential impacts on ecosystems and human health in northern Europe, Sci. Total Environ., 576, 22-35, https://doi.org/10.1016/j.scitotenv.2016.10.061, 2017.

Katragkou, E., Zanis, P., Tsikerdekis, A., Kapsomenakis, J., Melas, D., Eskes, H., Flemming, J., Huijnen, V., Inness, A., Schultz, M. G., Stein, O., and Zerefos, C. S.: Evaluation of near-surface ozone over Europe from the MACC reanalysis, Geosci. Model Dev., 8, 2299-2314, https://doi.org/10.5194/gmd-8-2299-2015, 2015.

Klingberg, J., Björkman, M. P., Pihl Karlsson, G., and Pleijel, H.: Observations of Ground-level Ozone and $\mathrm{NO}_{2}$ in Northernmost Sweden, Including the Scandian Mountain Range, Ambio, 38, 448-541, 2009.

Klingberg, J., Karlsson, P. E., Pihl, Karlsson, G., Hu, Y., Chen, D., and Pleijel, H.: Variation in ozone exposure in the landscape of southern Sweden with consideration of topography and coastal climate, Atmos. Environ., 47, 252-260, 2012.

Kumar, A., Wu, S., Weise, M. F., Honrath, R., Owen, R. C., Helmig, D., Kramer, L., Val Martin, M., and Li, Q.: Freetroposphere ozone and carbon monoxide over the North Atlantic for 2001-2011, Atmos. Chem. Phys., 13, 12537-12547, https://doi.org/10.5194/acp-13-12537-2013, 2013.

Lacressoniere, G., Foret, G., Beekman, M., Siour, G., Engardt, M., Gauss, M., Watson, L., Andersson, C., Colette, A., Josse, B., Macrecal, V., Nyirui, A., and Vautard, R.: Impacts of regional climate change on air quality projections and associated uncertainties, Climatic Change, 136, 309-324, https://doi.org/10.1007/s10584-016-1619-z, 2016. 
Lamarque, J.-F., Bond, T. C., Eyring, V., Granier, C., Heil, A., Klimont, Z., Lee, D., Liousse, C., Mieville, A., Owen, B., Schultz, M. G., Shindell, D., Smith, S. J., Stehfest, E., Van Aardenne, J., Cooper, O. R., Kainuma, M., Mahowald, N., McConnell, J. R., Naik, V., Riahi, K., and van Vuuren, D. P.: Historical (1850-2000) gridded anthropogenic and biomass burning emissions of reactive gases and aerosols: methodology and application, Atmos. Chem. Phys., 10, 7017-7039, https://doi.org/10.5194/acp-10-7017-2010, 2010.

Langner, J., Bergström, R., and Pleijel, K.: European scale modeling of sulfur, oxidised nitrogen and photochemical oxidants, Model development and evaluation for the 1994 growing season, Swedish Meteorological and Hydrological Institute, Norrköping, Sweden, SMHI RMK No. 82, 71 pp. (with errata), available at: http://www.smhi.se/polopoly_fs/1.35257!/RMK82.pdf (last access: 3 March 2017), 1998.

Langner, J., Engardt, M., Baklanov, A., Christensen, J. H., Gauss, M., Geels, C., Hedegaard, G. B., Nuterman, R., Simpson, D., Soares, J., Sofiev, M., Wind, P., and Zakey, A.: A multi-model study of impacts of climate change on surface ozone in Europe, Atmos. Chem. Phys., 12, 10423-10440, https://doi.org/10.5194/acp-12-10423-2012, 2012a.

Langner, J., Engardt, M., and Andersson, C.: European summer surface ozone 1990-2100, Atmos. Chem. Phys., 12, 10097-10105, https://doi.org/10.5194/acp-12-10097-2012, 2012b.

Lefohn, A. S., Malley, C. S., Simon, H., Wells, B., Xu, X., Zhang, L., and Wang, T.: Responses of human health and vegetation exposure metrics to changes in ozone concentration distributions in the European Union, United States and China, Atmos. Environ. 152, 123-145, https://doi.org/10.1016/j.atmosenv.2016.12.025, 2017.

Lelieveld, J. and Dentener, F. J.: What controls tropospheric ozone?, J. Geophys. Res., 105, 3531-3551, https://doi.org/10.1029/1999JD901011, 2000.

Logan, J. A., Staehelin, J., Megretskaia, I. A., Cammas, J. P., Thouret, V., Claude, H., de Backer, H., Steinbacher, M., Scheel, H. E., Stübi, R., Fröhlich, M., and Derwent, R.: Changes in ozone over Europe: Analysis of ozone measurements from sondes, regular aircraft (MOZAIC) and alpine surface sites, J. Geophys. Res., 117, D09301, https://doi.org/10.1029/2011JD016952, 2012.

Markakis, K., Valari, M., Engardt, M., Lacressonniere, G., Vautard, R., and Andersson, C.: Mid-21st century air quality at the urban scale under the influence of changed climate and emissions case studies for Paris and Stockholm, Atmos. Chem. Phys., 16, 1877-1894, https://doi.org/10.5194/acp-16-1877-2016, 2016.

Miyazaki, K., Eskes, H. J., and Sudo, K.: A tropospheric chemistry reanalysis for the years 2005-2012 based on an assimilation of OMI, MLS, TES, and MOPITT satellite data, Atmos. Chem. Phys., 15, 8315-8348, https://doi.org/10.5194/acp15-8315-2015, 2015.

Monks, P. S., Archibald, A. T., Colette, A., Cooper, O., Coyle, M., Derwent, R., Fowler, D., Granier, C., Law, K. S., Mills, G. E., Stevenson, D. S., Tarasova, O., Thouret, V., von Schneidenmesser, E., Sommariva, R., Wild, O., and Williams, M. L.: Tropospheric ozone and its precursors from the urban to the global scale from air quality to short-lived climate forcer, Atmos. Chem. Phys., 15, 8889-8973, https://doi.org/10.5194/acp15-8889-2015, 2015.
NV: Precisering av frisk luft, available at: http://www.naturvardsverket.se/en/ Environmental-objectives-and-cooperation/

Swedens-environmental-objectives/

The-national-environmental-objectives/Clean-Air/

Specifications-for-Clean-Air/ (last access: 21 March 2017), 2015.

Ohara, T., Akimoto, H., Kurokawa, J., Horii, N., Yamaji, K., Yan, X., and Hayasaka, T.: An Asian emission inventory of anthropogenic emission sources for the period 1980-2020, Atmos. Chem. Phys., 7, 4419-4444, https://doi.org/10.5194/acp-7-44192007, 2007.

Oltmans, S. J., Lefohn, A. S., Harris, J. M., Galbally, I., Scheel, H. E., Bodeker, G., Brunke, E., Claude, H., Tarasick, D., Johnson, B. J., Simmonds, P., Shadwick, D., Anlauf, K., Hayden, K., Schmidlin, F., Fujimoto, T., Akagi, K., Meyer, C., Nichol, S., Davies, J., Redondas, A., and Cuevaso, E.: Long-term changes in tropospheric ozone, Atmos. Environ., 40, 3156-3173, 2006.

Parrish, D. D., Law, K. S., Staehelin, J., Derwent, R., Cooper, O. R., Tanimoto, H., Volz-Thomas, A., Gilge, S., Scheel, H.-E., Steinbacher, M., and Chan, E.: Long-term changes in lower tropospheric baseline ozone concentrations at northern mid-latitudes, Atmos. Chem. Phys., 12, 11485-11504, https://doi.org/10.5194/acp-12-11485-2012, 2012.

Parrish, D. D., Law, K. S., Staehelin, J., Derwent, R., Cooper, O. R., Tanimoto, H., Volz-Thomas, A., Gilge, S., Scheel, H.-E., Steinbacher, M., and Chan, E.: Lower tropospheric ozone at northern midlatitudes: changing seasonal cycle, Geophys. Res. Lett., 40, 1631-1636, https://doi.org/10.1002/grl.50303, 2013.

Parrish, D. D., Lamarque, J.-F., Naik, V., Horowitz, L., Shindell, D. T., Staehelin, J., Derwent, R., Cooper, O. R., Tanimoto, H., Volz-Thomas, A., Gilge, S., Scheel, H.-E., Steinbacher, M., and Fröhlich, M.: Long-term changes in lower tropospheric baseline ozone concentrations: Comparing chemistry-climate models and observations at northern midlatitudes, J. Geophys. Res.-Atmos., 119, 5719-5736, https://doi.org/10.1002/2013JD021435, 2014.

Pozzoli, L., Janssen-Maenhout, G., Diehl, T., Bey, I. Schultz, M. G., Feichter, J., Vignati, E., and Dentener F.: Re-analysis of tropospheric sulfate aerosol and ozone for the period 1980-2005 using the aerosol-chemistry-climate model ECHAM5-HAMMOZ, Atmos. Chem. Phys., 11, 9563-9594, https://doi.org/10.5194/acp11-9563-2011, 2011.

Robertson, L. and Kahnert, M.: 2D variational data assimilation of near surface chemical species, edited by: Borrego, C. and Renner, E., Air pollution modelling and its application XVIII, Elsevier, Amsterdam, 2007.

Robertson, L., Langner, J., and Engardt, M.: An Eulerian limitedarea atmospheric transport model, J. Appl. Meteor., 38, 190-210, 1999.

Robichaud, A. and Ménard, R.: Multi-year objective analyses of warm season ground-level ozone and $\mathrm{PM}_{2.5}$ over North America using real-time observations and Canadian operational air quality models, Atmos. Chem. Phys., 14, 1769-1800, https://doi.org/10.5194/acp-14-1769-2014, 2014.

Royal Society: Ground level ozone in the 21st century: future trends, impacts and policy implications, Science Policy report 15/08, the royal society, London, UK, available at: https://royalsociety.org/ /media/Royal_Society_Content/policy/ 
publications/2008/7925.pdf (last access: 16 November 2017), 2008.

Schultz, M. G., Backman, L., Balkanski, Y., Bjoerndalsaeter, S., Brand, R., Burrows, J. P., Dalsoeren, S., de Vasconcelos, M., Grodtmann, B., Hauglustaine, D. A., Heil, A., Hoelzemann, J. J., Isaksen, I. S. A., Kaurola, J., Knorr, W., LadstaetterWeißenmayer, A., Mota, B., Oom, D., Pacyna, J., Panasiuk, D., Pereira, J. M. C., Pulles, T., Pyle, J., Rast, S., Richter, A., Savage, N., Schnadt, C., Schulz, M., Spessa, A., Staehelin, J., Sundet, J. K., Szopa, S., Thonicke, K., van het Bolscher, M., van Noije, T., van Velthoven, P., Vik, A. F., and Wittrock, F.: Reanalysis of the Tropospheric chemical composition over the past 40 years (RETRO) - a long-term global modeling study of tropospheric chemistry, Final report, edited by: Schultz, M. G., Reports on Earch System Science, 48/2007, Max Planck Institute for Meteorology, Hamburg, Germany, available at: https://www.mpimet.mpg.de/fileadmin/ publikationen/Reports/WEB_BzE_48.pdf (last access: March 2017), 2007.

Simon, H., Reff, A., Wells, B., Xing, J., and Frank, N.: Ozone trends across the United States over a period of decreasing NOx and VOC emissions, Environ. Sci. Technol., 49, 186-195, https://doi.org/10.1021/es504514z, 2015.

Simpson, D., Guenther, A., Hewitt, C. N., and Steinbrecher, R.: Biogenic emissions in Europe: 1. Estimates and uncertainties, J. Geophys. Res.-Atmos., 100, 22875-22890, 1995.

Simpson, D., Benedictow, A., Berge, H., Bergström, R., Emberson, L. D., Fagerli, H., Flechard, C. R., Hayman, G. D., Gauss, M., Jonson, J. E., Jenkin, M. E., Nyíri, A., Richter, C., Semeena, V. S., Tsyro, S., Tuovinen, J.-P., Valdebenito, Á., and Wind, P.: The EMEP MSC-W chemical transport model - technical description, Atmos. Chem. Phys., 12, 7825-7865, https://doi.org/10.5194/acp-12-7825-2012, 2012.

Simpson, D., Arneth, A., Mills, G., Solberg, S., and Uddling, J.: Ozone - the persistent menace: interactions with the $\mathrm{N}$ cycle and climate change, Current opinion in Environ, Sustainabilty, 9, 919, 2014.

Stocker, T. F., Qin, D., Plattner, G.-K., Alexander, L. V., Allen, S. K., Bindoff, N. L., Bréon, F.-M., Church, J. A., Cubasch, U., Emori, S., Forster, P. Friedlingstein, P., Gillett, N. Gregory, J. M., Hartmann, D. L., Jansen, E., Kirtman, B., Knutti, R., Krishna Kumar, K., Lemke, P., Marotzke, J., Masson-Delmotte, V., Meehl, G. A., Mokhov, I. I., Piao, S., Ramaswamy, V. Randall, D., Rhein, M., Rojas, M., Sabine, C. , Shindell, D., Talley, L. D., Vaughan, D. G., and Xie, S.-P.: Technical Summary, in: Climate Change 2013: The Physical Science Basis, Contribution of Working Group I to the Fifth Assessment Report of the Intergovernmental Panel on Climate Change, edited by: Stocker, T. F., Qin, D., Plattner, G.-K., Tignor, M., Allen, S. K., Boschung, J., Nauels, A., Xia, Y., Bex, V., and Midgley, P. M., Cambridge University Press, Cambridge, United Kingdom and New York, NY, USA, 2013.
Verstraeten, W. W., Neu, J. L., Williams, J. E., Bowman, K. W., Worden, J. R., and Folkert Boersma, K.: Rapid increases in tropospheric ozone production and export from China, Nat. Geosci., 8, 690-697, 2015.

Watson, L., Lacressoniere, G., Gauss, M., Engardt, M., Andersson, C., Josse, B., Marecal, V., Nyiri, A., Sobolowski, S., Siour, G., and Vautard, R.: The impact of meteorological forcings on gas phase air pollutants over Europe, Atmos. Environ., 119, 240 257, 2015.

Watson, L., Lacressonnire, G., Gauss, M., Engardt, M., Andersson, C., Josse, B., Marcal, V., Nyiri, A., Sobolowski, S., Szopa, S., Siour, G., and Vautard, R.: Impact of emissions and $+2{ }^{\circ} \mathrm{C}$ climate change upon future ozone and nitrogen dioxide over Europe, Atmos. Environ., 142, 271-285, https://doi.org/10.1016/j.atmosenv.2016.07.051, 2016.

WHO: WHO Air quality guidelines for particulate matter, ozone, nitrogen dioxide and sulfur dioxide. Global update 2005, Summary of risk assessment, WHO press, World Health Organization, Geneva, Switzerland, available at: http://www.who. int/phe/health_topics/outdoorair/outdoorair_aqg/en/ (last access: 3 March 2017), 2006.

Xing, J., Mathur, R., Pleim, J., Hogrefe, C., Gan, C.-M., Wong, D. C., Wei, C., Gilliam, R., and Pouliot, G.: Observations and modeling of air quality trends over 1990-2010 across the northern hemisphere: China, the United States and Europe, Atmos. Chem. Phys., 15, 2723-2747, https://doi.org/10.5194/acp-152723-2015, 2015.

Zanis, P., Hadjinicolaou, P., Pozzer, A., Tyrlis, E., Dafka, S., Mihalopoulos, N., and Lelieveld, J.: Summertime free-tropospheric ozone pool over the eastern Mediterranean/Middle East, Atmos. Chem. Phys., 14, 115-132, https://doi.org/10.5194/acp-14-1152014, 2014.

Zhang, Y., Bocquet, M., Mallet, V., Seigneur, C., and Baklanov, A.: Real-time air quality forecasting, Part II: State of the science, current research needs, and future prospects, Atmos. Environ., 60 , 656-676, https://doi.org/10.1016/j.atmosenv.2012.02.041, 2012. 